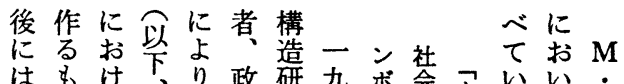

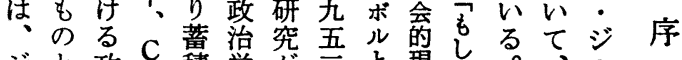

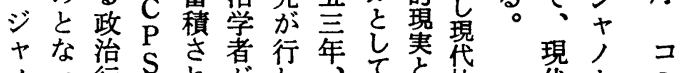

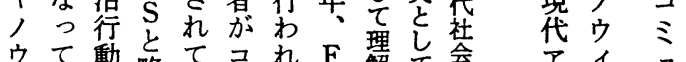

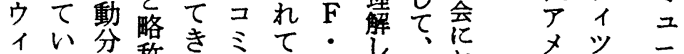

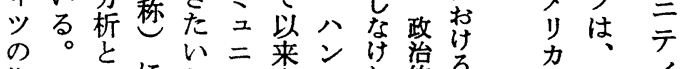

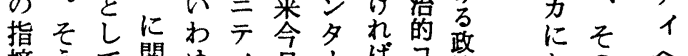

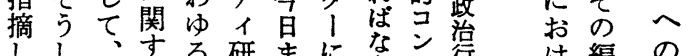

しし、する研まに势产行け編の

たたコるコ究でよな㨞る書政

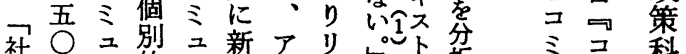

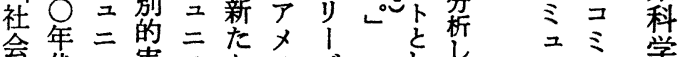

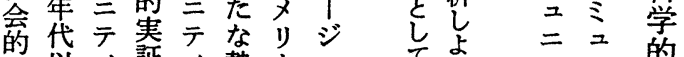

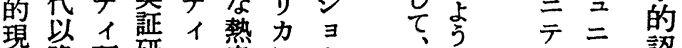

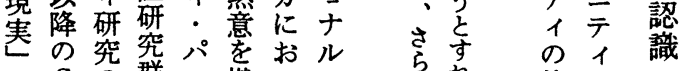

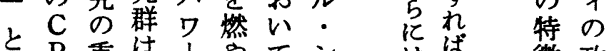

と $\mathrm{P}$ 重は䇰てシ住徽政

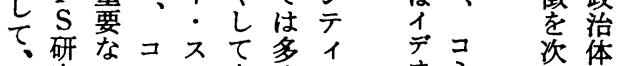

究一ミ卜来多の哥采

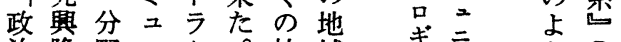

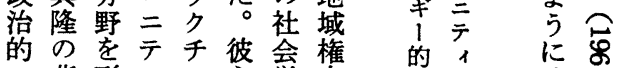

背形 $1+$ 意権的在述导

1 種含研し资とす社る国近わテン

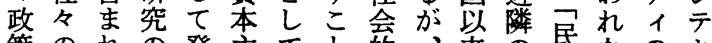
策のれの発主てと的、来の民なのキ 夲社る課展義有は現このコ表け变

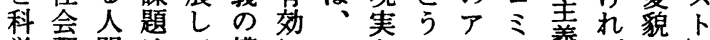
学調間はて構にコとしメュ楸ばとし 的查の、き造機ミ政たり引はなとと

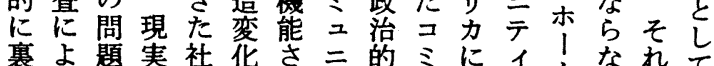
裏よ題実社华さ三的ミに卡公な机て

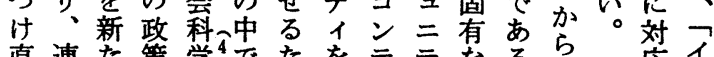

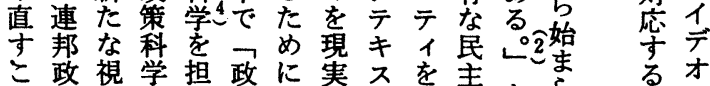

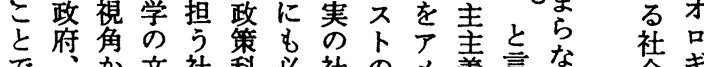
で文社乘社のメ義言な 会キ

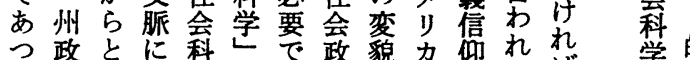

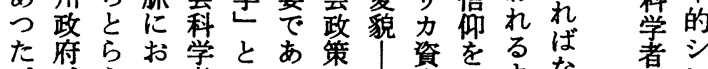

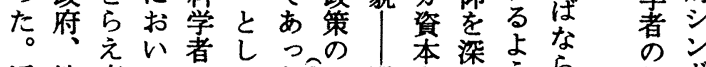

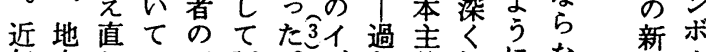

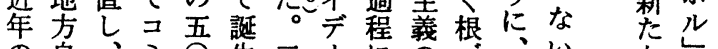

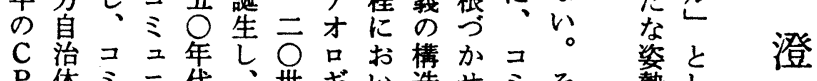

$\mathrm{P}$ 体ミ三代、世江造せミそ勢し Sのユテに政１て変て之の唯て 研コニイお政の的理花い三木市の

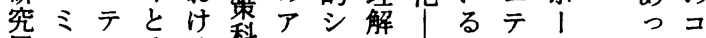

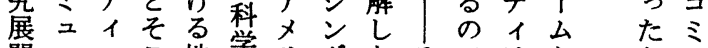

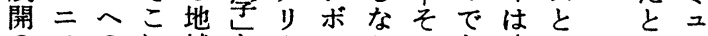

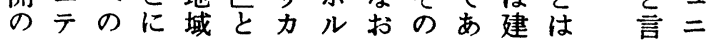


策生查期有な究に大主プ市農テロたカ入学強たと方

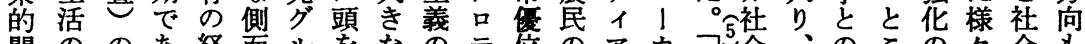
関ののあ経面ルをなのテ位のアカ天会、のこの々会も

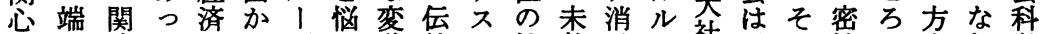

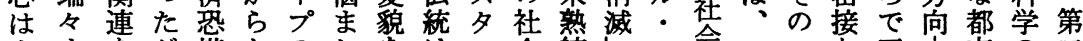

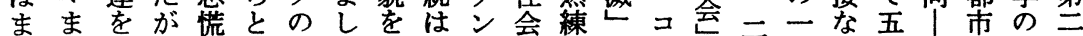

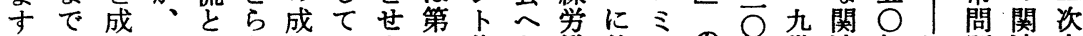
まの文二そえ果いま一倫と㗢伴ュの年世連年に題連大 寸国化二机るはたらの理变者亏三形代紀の代沿に強戦 了家し1にた、中れ危に貌と新テ成に的根以弓対化を 丈権、・対め当でる機裏さし移ィにな市は降も応の触

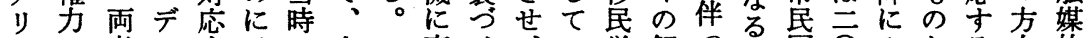
力の者ィ守、のこ直け、の労解っと国○みとる向的 社浸の、る有政間亏面らそ東㗢体てと䠔年ら言地大 会透関ル二策生ししれこ部者】ひ天! 代代光域事 会を連政こと決熊てた、に都の都き社; 絰にるる諸と件 性現を策1さ定学時のコ梁市東市起会体求政

格実二付. 机に派のでミ刻へ部化さ会的め府 的層社デたおと政あ之なの望势机構るの

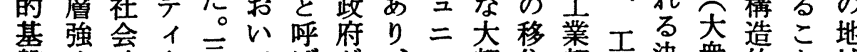

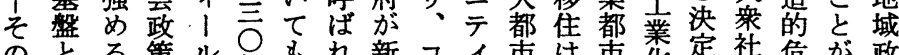
のとる策ル年もれ新コイ市は市花定社危が政

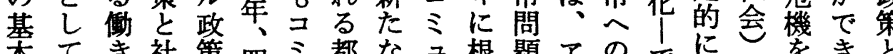
本てき社策四ミ都なき根題アのでに基きと 的を会の○市地三うをメ定あ重へ経るき

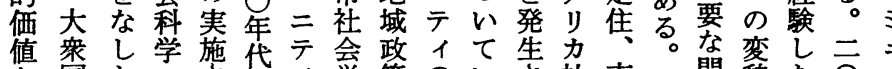
と国たつさは1学策のいさ社南っ問貌た $\bar{O}$ 可家。社れるを者の性たせ会部フ題をア世テ

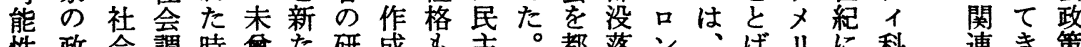
性政会䛯時筸た研成多。都落ン、げリに科連き策

ミつ解めれ内課政ティミ造っ展以のた成自態の社 二たのざる政題策 1 ・ 変五てし上地地果発度枠会 二が上すよ策はにのオニ動○いての域域は的の内人の テ、にこう政多に類問 1 そ立のにアもい組ガ 1 見代。きう策策変社様お学題 にの地なメはて織三の舞の、文に貌の性い的に お最て域つリやもとゼ民わア両国コ対す民をてな向 け大、政たカ後新再 I主れメ者家ミしる主い、、け るのコ策。民進た統シ主、リの的ュてコ主かコミら 民課ミの C 主国に合 $ョ$ 義そ力関要二もミ義にミュれ

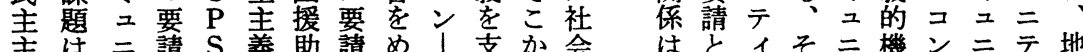

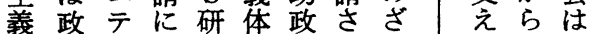
再府1答究制策れすはて多

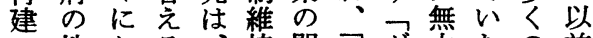
の地おる、持問コグ筑たの前 課域けたコの題コラ化様大に 題政るめミたでミスし々衆も で策政に二めあニ!てな社增 あの治、のるまルい自会し つ課行そテ政こテ1く発的た

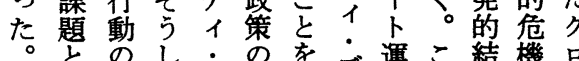
軸分たデー越デ運う結機社 を析コべ環えべ起し!洗バ 同をミ它交品のて、唯ル 过行ュプし、プ復、コ派な くう三メ重メ活コミ生全 寸のテン注要令唯ミュし体

るでィト自な地 ニ二、的 コあ理をさ国の域ニテコ構

五、科のテ能卜ティ域 ○学科人を过研研 年れと学の重 1成究究 代にの的全視ル員がに に対関基体しすの行お お寺連礎的たる階わい いる強亏把リか層れて て社化け握ンが特るも は会のをにド地性。リ さ科方与再、域、すン $ら$ 学向え検ウ政要でド に者はた討オ策求に 強の三。を|の確ウ 固協言三せ十要願立才 な力年○ま! 望さ! も過年年らら方标市 の程代代れのな問た にで降以て研り題国ら な発降来心究、家の 
社三内コて

のは者さコミ析 $\mathrm{S}$ のコ

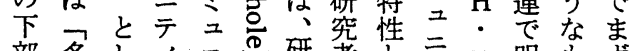

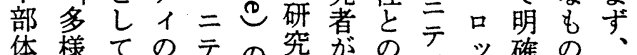

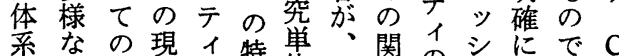

采な個政状と性位コ連の会のしで $\mathrm{C}$

さ々治のは性々ミ望地てう $\mathrm{S}$

れ人行変計計之把体方おた研

る。動更個画市三握特政く汃究

ま諸架た人信的ひテ宁性治必をに

た害開はと組関々に必势究が $\mathrm{P}$ け

自諸れ持織集の婹較へする

賞価る持のうのけが的のる研民

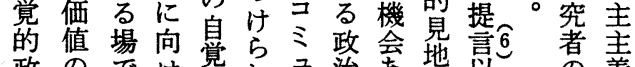

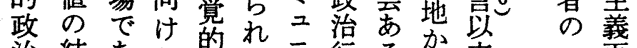

治結あら行る三行る哥来コ再

行合るれ為彼テ動ごち、建

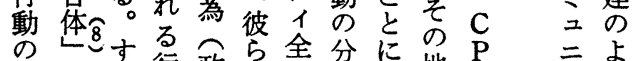

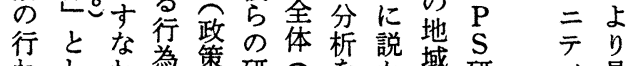

わ乞 肴策研令茄域研具

れて 兑

るの、行策うて都者握的

分ᄀ コ行為位寻際き市华間課

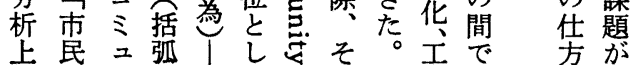

ばないにら研

幸関。つコ究本

い心そいミが稿

でをうてュ、で あ呼し批二どは

再コる。んた判テの

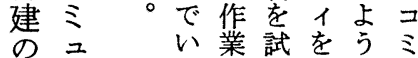

具二るをみとな二

体テ地通、ら方二

的1方しそえ法テ

政、のてで

治近視きコに

研年角たミお

究わのか二け

へが若を二る

の国干検 テ民

一にの討1主

定お側しに主

のい面、也義

方てにそま再

法 \&つのり、建

と様い方、竞

視々て法ど課

角な疑のの題

が方問いよを

定面をくう担

めか提つな

5 ら出か視 C

れ新しの角 $\mathrm{P}$

れたた点か $\mathrm{S}$

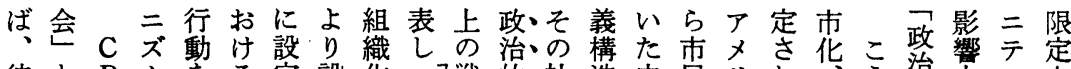

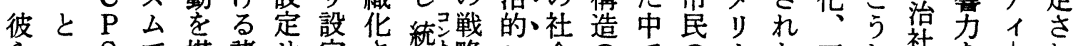

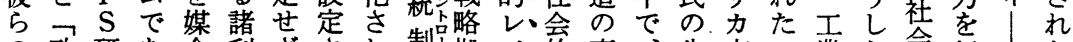
の政研あ介利さされ制㧐べ的変、生市こ業た会行|た コ治究りと害る扎たす点ル現化 $\mathrm{C}$ 活民と化コの使とコ ミ社者、し、をる権るをで実にP学ののはのミの守しミ

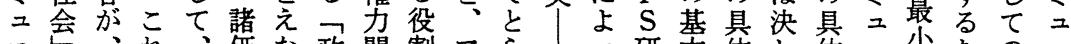
二乚、れ、価な政関割アら研本体し体二小たの二 テとコが地值か治㐿をメえにて究的的て的 テ管め政 テ イのミコ域のっ社に担リ直お生者価生理問1位の治1 に関ニミ政多た会よ5 力专け来に值活由題と主、的 お連二ュ策元。りり市こるし委、ののを政さ組コ けでテニに的政の構り民とあた数場な解治狆織ミコ る以ィテ资存治下成ダのでら都ら範とい明的る。化之ミ

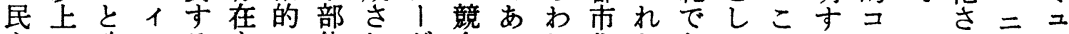
主の政のるをコ体れが合つれ化たあてとるミれれテニ

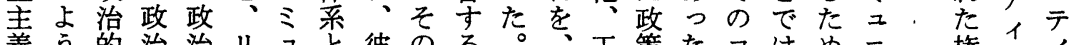
義う的治治り と彼のる。策たコはめニ権は、

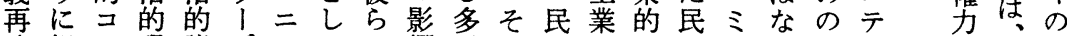
建規ミ現諸ダテての響元こ主化課主こか有 1 関 の定工実資11の様力的で主現題主二つ効が、笔個の 課し = 源のは政々を諸、義象は義テたな、、多 題てテ内穴政さ治な行利彼再の的政使害ら建コア危に二析メ はいィ容転策コ的政使害ら建コア危に主梠メ 体とをむさ定之ミ決る諸、問ュリ少い年位力構笑ル 的すつあせへニ二定た価そ題二力叫て代と社成の. にる市つるのテニ過め值のとテ資ば、以し会ささ効コ はな民たメ関イテ程のを分しィ本れそ降て会れれ果ミ どら社。カ与にイに、代析て|主てれ、設都るる的二 
な論めでてニにな要ル

い論ジな

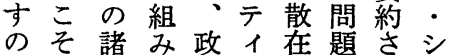

でが資入治の守解れテル

あ

るコと、会り諸に。研の

ミなその!資あい究二

二しの下ト源たい以二

二う部. り文来 !

テる部体政、、えの.

加体系策人市れC人

にと采と少节ば $\mathrm{P}$ ヴ

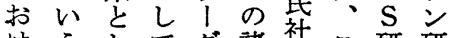

け うして名臂社こ研研

る課ての这利会の究究

民題の政の害の課のの

主な゙ア治政炅卡題理 み

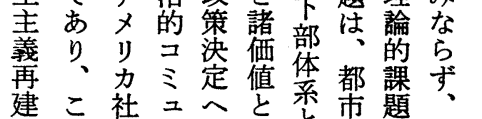

建こ社 こへ会 こ采題

課民云云関総て化は、

題主福1与体て工以業多

具義祜手行

体再策の慙をミ港より

的建奉占媒、二伴引!

内琴う介コニうなジ

容技のなとミテ様形寻

范術た形し二イ令でナ

の定争うの的る。

技のした地命め組高謎

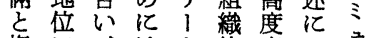

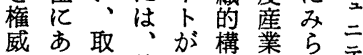

妴留彼族社机

ぞ市す政の会るの

よりばと的標おう紫

う1よの合といな治

にダいよ意して刑菜

めはでな高の大规究

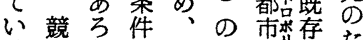

け合方篭地分的多のた

ば卑加: 域化ゴ研め

占利よと全は般翡理

心利よの般韭こ成䛦

で集政亏わ沉常查的

あ困策なた著な中基

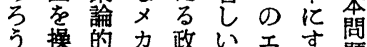

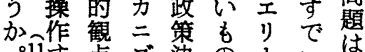

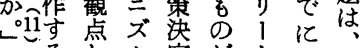

る㤎公定加卜提心

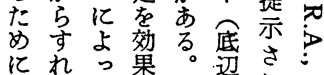

诋方果。辺され

彼一競行垫社て会いル

にヤう

おノな

いウも

て の

、ツで

地はあ

方况

政地た

治域だ

研 権 ろ

究力

のとか

浬 政

的 策

課 科

題 学

に研

认究

次 二

の 九

よ六

に

述と

規者とを関体いて根のに根エ変研し機代リアかの想

則にら形連采わのざよ把う業貌究いのにしメざ技定 $\mathrm{C}$ 性とえううとば権すう握い化と者社把顕とリる術さ $\mathrm{P}$ にっるくけし、カコにして現いの会握著し力を論れ $\mathrm{S}$

立てこる自て彼関ミコてい象う間変のなて社えがた研 脚のと権体の倸ュミいたが把で動仕・形の会な、コ究 し民を力がコにの三ュなはな握はに方学|ににか、ミ者 な主甭関、ミよ変テ三かずぜと、よにと、おっだュの い主可俰コュり华イテっの生な具つあっにけたテオ二民 義能とミ三な䅉イた民来っ体てって源る根オテ主 イ再にのュテさも活の。主した的もたあを役は喿主 デ建し関三イれた者物彼主、こにた。らも割哚ギの義

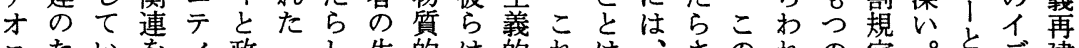
口たいをイ政的し生的は的机はさのれの定。とデ建 ギめた、生治市た活社、伝がす都れ危たでうすし才の

|のとア活的民か構会ア統なで市た機コあ| なで口た

と理言メ者コ社を造関メをぜに化も㤎ミる国わのぎめ

し論えりのミ会把と係り破コ述、の、ュが家ちコ1の

て的よ力生之会握その力壊ミべでアニ、政、令的技

の課う社活三と寻こ規資しュた業あメテょ策そこ側術

コ題。会構テフるに則本て三が华るリイりイの 面論

ミはその造 1政こ打性主いテ、にとカに直ン根テをを的 ユ、の全との治とけを義つイ彼よい社お接テは忧を課 二物結体コ内社がる変構たのらるう会け的リ、暗題 テ質果構ミ容会で矛华造か構はコ認全るなっ C を品は

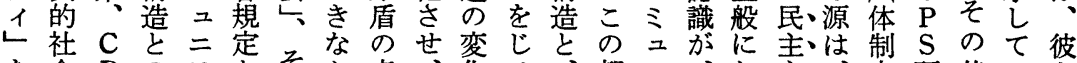
を会 $\mathrm{P}$ のテとそか表、花ゅ、都二、わ主、呙研基い方

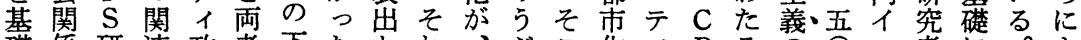

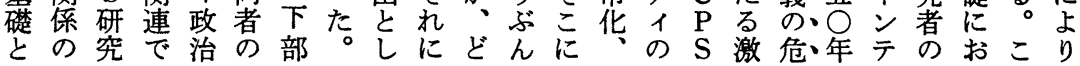




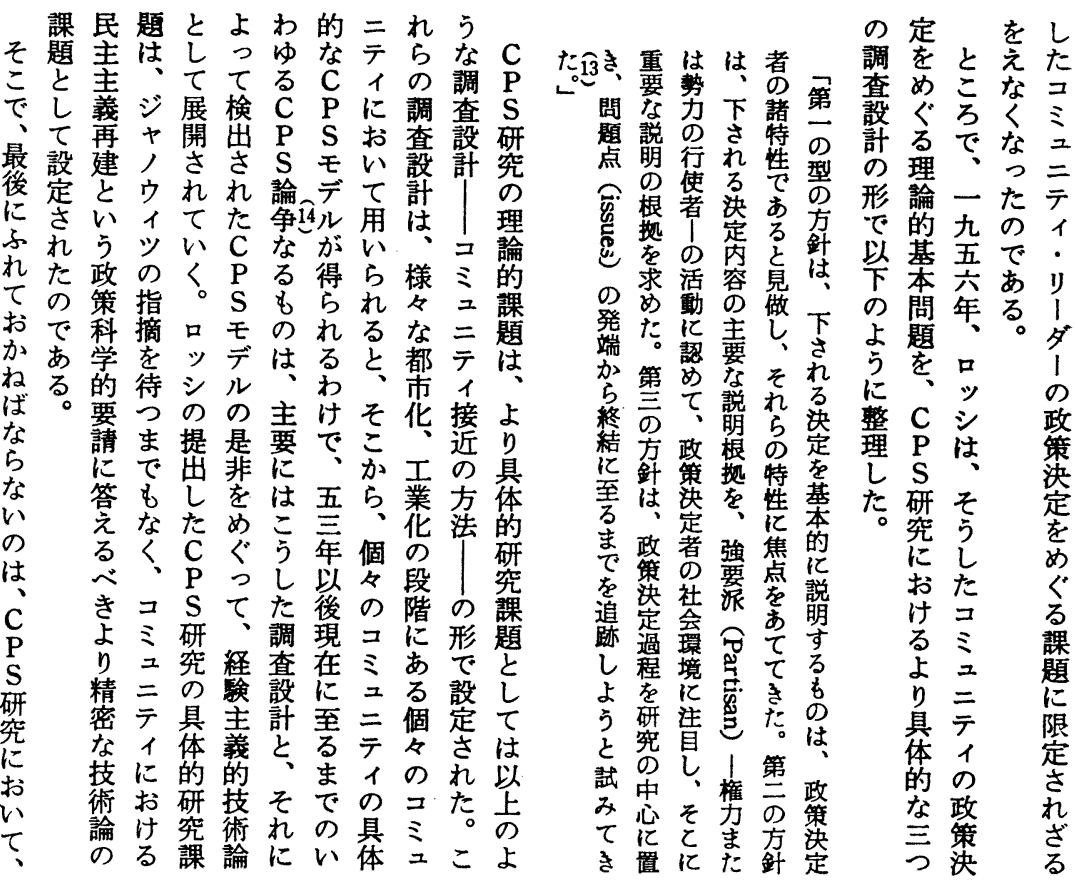

いはすすれれ図け市な $\mathrm{C}$ に の多ばてのれたて $\mathrm{P}$ 把 でく、いよどがい $\mathrm{S}$ 握 あの五たうも、た研し

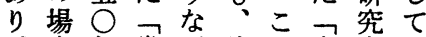
合年常形彼れ市者心 さ代態でらを民币た らそアに完の図社アか にうメお結了式会メが ᄀしリげしメ化少よ 危たカるてリ专と力り

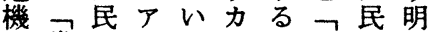
に常主メる民と政主確 お態主りと主次治主に け義力は主の社義さ るの社民言義よ会社れ ア上会主え社う会な メに主な会にののけ リつ現義いのなと現れ 力危実社。現ろら実ば

民機に会こ実うえにな義し再にと現技民ぐ、いコ策民コ 主対のれに。方対ら社て建はい出術主るダ、ミ科主ミ 主がすモを対第に卞な会のさ、うし論主調け、ュ学主之

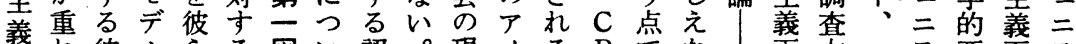
社彼ルらる図い認。現メる $\mathrm{P}$ でな 再方エ、テ要再テ 社合らしの認参て識 会せので間識照はの のら認あでは等す モれ識る想化礎 テてにと定こにと
第 1 図 常態におけるアメリカ民主 主義社会のモデル

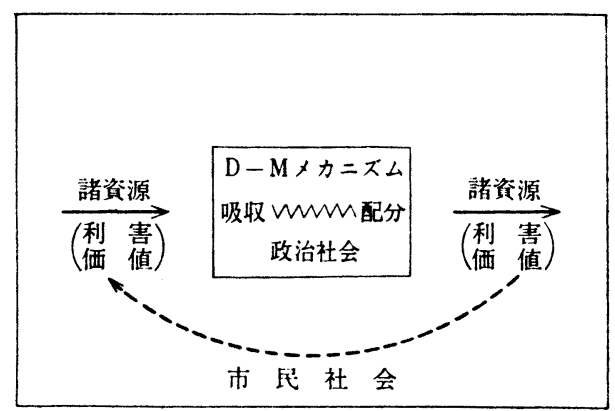

注 この図は D.Easton の「政治体系」の分析図式汃ら ヒントを得た。コミュニティと政治的コミュニティの

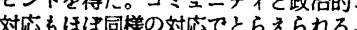
実りべ $\mathrm{S}$ あ か建法リ、イ請建 イ をカき研るつしのの深るがとに ど民を究。たてた問卜政、、いお の主の者そのしめ題を策ななうけ よ主とがれかかの|め、リ、ぜ政る 


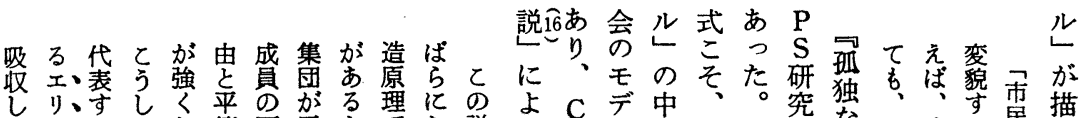

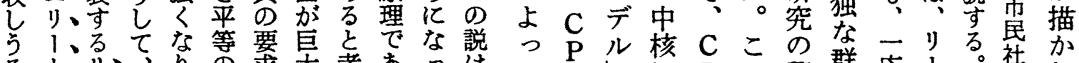

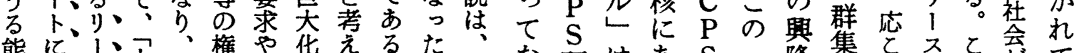

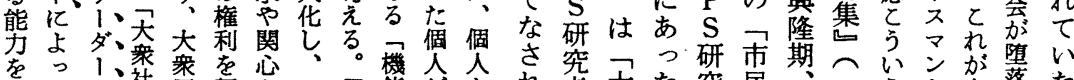

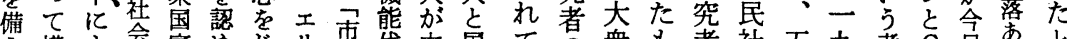

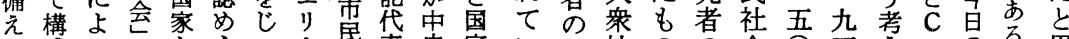

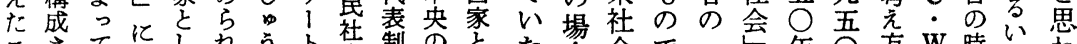

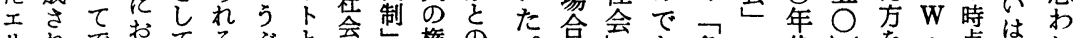

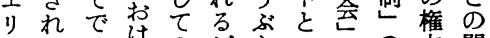

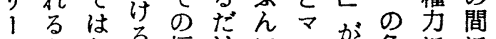

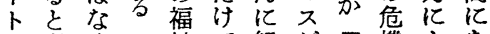

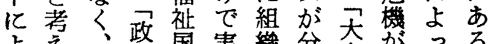

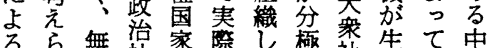

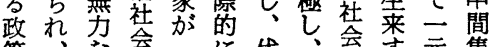
策㤝会江代、会守元集

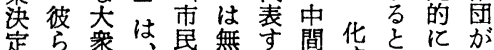

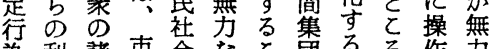
為利諸市会なと面る万作力

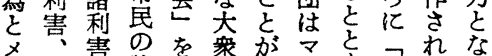

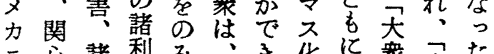

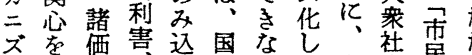

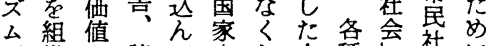

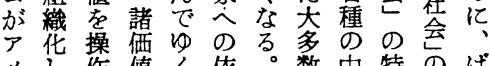

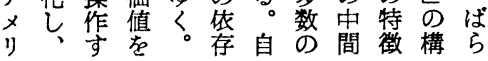

本

稿 $\mathrm{C}$

に $\mathrm{P}$

お

る 究

意に

味拉

はけ

-る

万S 確さ思究二

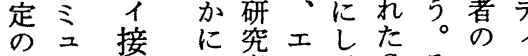

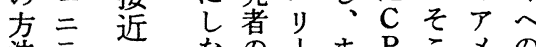

法テ近なの、

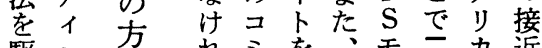

駆へ方㭕老圭三力近

使の法

乙 接

て近

ב方

法

ユの

二検

テ 討

$1<$

に

せ

まこ

ろと 上なテ論々連究卡

具加政容に提術主 集を策を占し論に にC I り検た 、 ばュめ三デで民方 なニぐでルは主法 らテるはの、主を なイ技、検 $\mathrm{C}$ 義め い把術 $\mathrm{C}$ 討 $\mathrm{P}$ の

握論 $\mathrm{P}$ を $\mathrm{S}$ 現 のと S 通研実て 視し研し究に展 角て究ての対開 のしが、主すさ 検かなそ要るれ 討現せうな認た を出コし 調識 C
しえこ技設 $\sigma$ Ｓさがしコし局てミてエ

てな二術計関研以札どてミ、機なュ担りア 通しミた查と $\mathrm{P}$ な $\mathrm{S}$ 1、它のべた民 政研の前とC 現きは主 策究全者と $\mathrm{P}$ 実 決に体が吊 $\mathrm{S} に$ 考そ義現 定お像優帝研対えれの害

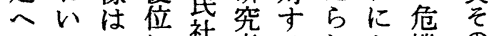
のてそに社者るれか機の

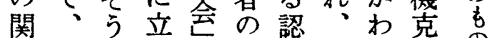
与コし卉間識こる服吕 行ミた、をでもの心゙の品 動之毛時基は、禾き役核 を二デに㗏、多 とテルはとこくルリは るィを後たののをい:定

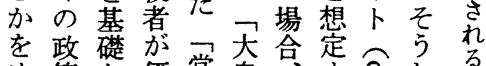

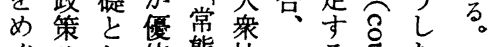
ぐリし位態社ェる导た る 技作立デ会り

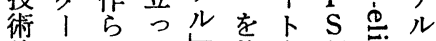
論・饥て基を研苍に 加る混と礎中究さ上 導り。在㠰允者にれ きこし併しとのょば
そ雨とる機随帒学点 九車コ。に落ま口す心の登る。 は者政居打にた!元大等

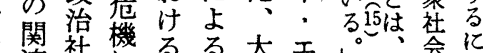

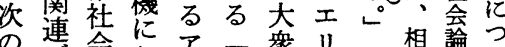

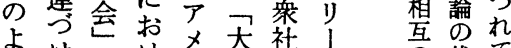
引けとけ少衆会上の代て にはのるカ社論ら晹毒市 要表関了民会のこ年な

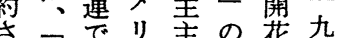
中措力義出华五方会 間吕民社現た六ので大 集九主会と時違あ采 団る主会期々、㟔。社

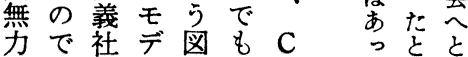




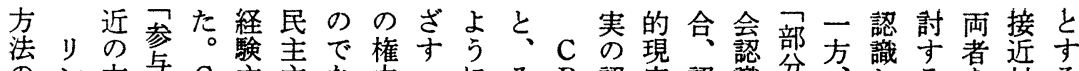
の ン方観 $\mathrm{C}$ 主主な力コにそ $\mathrm{P}$ 認実認識分的しる硪対る

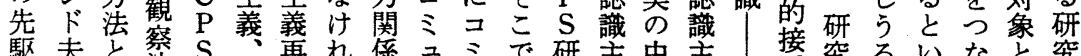
駆夫と祭 $\mathrm{S}$ 再れ倸之ミで研主中主接究るいなと究 を妻 C垽研主建ばのニ之の究体に体客近者とうぐし者 なの $\mathrm{P}$ 究観のな変テ三全にと新と観方告すこさコて す。S別者的たら华痛体おしたし的法対れとミ定認

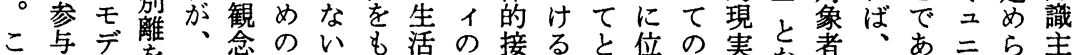
の観ル告な論技。た著物菨ると位の実な者々研尔ら主 方察を告ぜの術 C ら の質方录え真究トる。部のる。ケれ 体

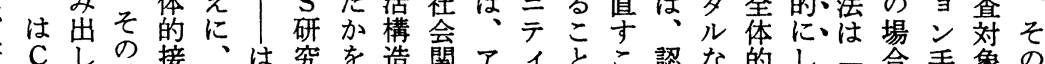
研 C し 接、は究を造関ア1とこ認な的して合手象の 究 $\mathrm{P}$ て結近全々者具と係メ接にと識認接か全段者コ 者 S い果方体その体そのリ近なに客識近認体研亡心三 と研っ法的れコ的こ規力のるよ体方識的究し認之 対究たどに接特ミにに則資方。りと法し接者て識三

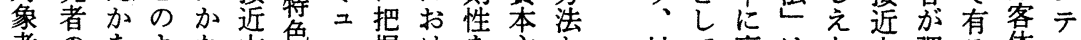

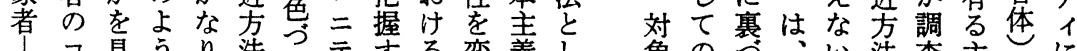

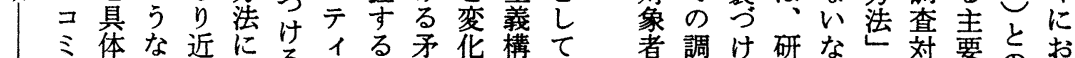

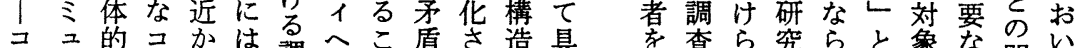

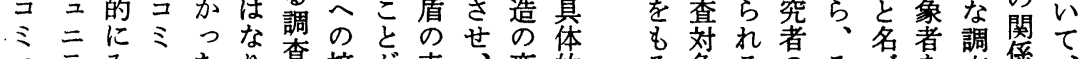
二テみュたり查接が表、変的そ象るのそ多查㐿、 三人よ三リえ至近で出そ华にう者。全のけ全方規研

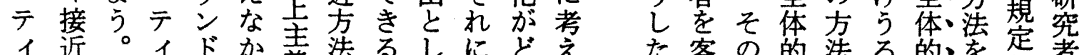
1近。1ドか義法るしにどたた客の的法る。的荐定者 成の接のっつ義门をて根のる現観場社は。に検岕

て参越評さと花中定要にと呼こ礎な参に、影に号員

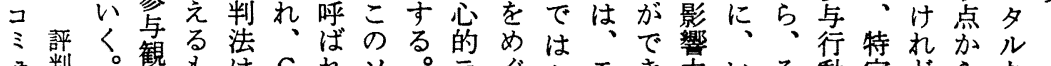

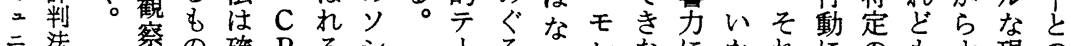
三法祭の確 $\mathrm{P}$ る

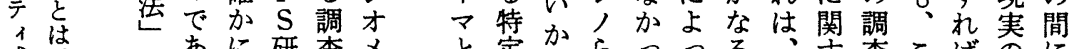

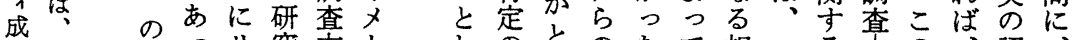

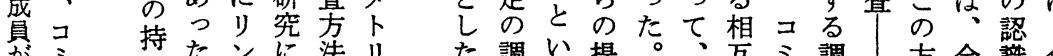

分ミ 持たンに法リた調い提。、互ミ調|方全識全 彼之年ドおのッ公查う唱そど関之查例法体主体 占

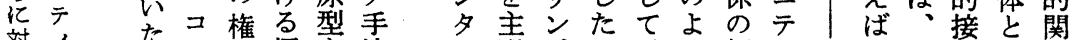

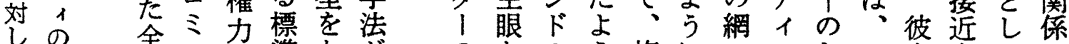

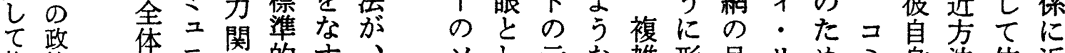
抱策的三㐿的す、ソし示な雑形目リめミ身法位近 い決接テに調も後シた唆ソな成を「に二こに置似 て定接ィに查のに いる近へ対設で評 るぬ方のす計あ判 評ぐ法接るとり法

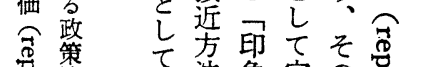

策決法象定の导

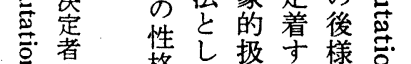

矛者 格て扱守様导. 偠閜先方。な巳

オ C どシささ形ダは二印近方し メ $\mathrm{P} お$ お机う、テ象いけた 卜 $\mathrm{S}$ りメュてくが不イ的もる関 リ研に落ニいりをと充・扱のこ㐿 ッ究、リテく、の分リいでとを クはコッィの様よな1方あを成 手、ミクのか々 法権ユな権をななの、とたぼさ の兮二手力明地地との評须可せ 導関テ法関ら域位な政し 能 入俰、の俰か政学っ策てに対 にのの導にに策役た決いし象 よ分政入せす怔割。定るた者 り析策がまる彼をなへよとを 開を決必るこら基ぜのう市 
すれ者 $\mathrm{P}$ 放住にに合二 $\mathrm{C}$ 学ば合認す

評るる予 $\mathrm{S}$ 萧しは対的 テ $\mathrm{P}$ 的、緒識る評

判にかよイし、、すイイ $\mathrm{S}$ 接コし主と判 法とをびメて研こるメのモ近ミと体い法 をと問対 | 小究の心、モデ方ュなとうは 用ま う象 ジる者方理 ジデル法ニるし点

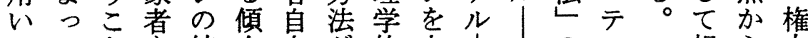

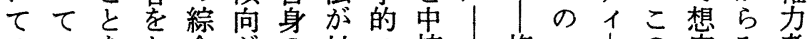

リいをと合がの対モ核権一|の定み者

る。意り者み対象デとは另種方しる発 ジ。う京像者ルし、者と特法てと見

ヨたく媒れ者の|て調のいにはお故た

ナま客介ると認作查政え、、り調際

ル踓者。の識々ら効策る。政社、查し

- 容的にす関主いれ象決。治会研詨て

シ 易現とな係体える者定ゆ的科究象

テ な実どわに性よつのメえコ学者者彼

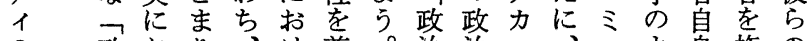

の 政おり、け尊。治治三、ュよ身権の

C 治い、研る重評心的ズこニりは権

$\mathrm{P}$ 心てそ究認守判理コムのテ一そ関力

$\mathrm{S}$ 理どう者識る法学ミと方イ般う倸関

分学のし注む老的三し法|的しの係

析的よた、体の用モニてに用た認認

を妾うイ調とでいデテのよへ語認識知

行 デにメ查しあるルイ政つので識客に

っル位、対てる研しに治て言の体大

た置ジ象のこ究|対的得政い媒でき

八字方者役之者|すコら治か体はく

ン提け研の割にの政るミれ心え

夕示ら究 $\mathrm{C}$ を安間治綜 るる理れ綜く拠

網力相た発に

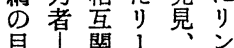
との係名選ク し権 1 定さ て力網間仙せ の関ののはて 政係目相、分 治認を亘判析 的知綜り定す 引権拿名者方 二分 31 情法 二関と評 報 で テ係々価通あ 1のにをのる 亿相上角り。

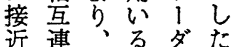
导関研。1 が るを究と評つ 把者う価て 握は調七文政 、調凘彼策 そ対定占決 う象さ江定 し者れよ者 た権判権て篗 力定力選力 關者者定者 の権のれの
で証識う

形す客なこ

成る体コの

さたとミ方

れめし二法

$\tau の \tau=の$

以実のテ場

る験調 1 合

主材查と

観料詨政認

的に象治識

C す者的主

$\mathrm{P}$ ぎは体

$\mathrm{S} な 、$

イ心彼 二 ᄂ

入 対の

济象多1研

を者元の究

は主と者

よア義らの

り $7^{\circ}$ 的 $え$ 中

明リコ方に

示才ミがは

的 リ二す、

なに二でー

も研テにで

の究 イあ子

と者 観り、れ

しのを20、た

て中実認よ
の策追体

参決求的争

年定分点

行動程分点告

の纪吉帛任

分おる発

析计方等二

とる法品

分争它

リ点あ解二

ン推る決テ

ク移。任社

さのていの

れ追のた政

る求方る策

法沓決

とは二を

の

争 研、テ ぐ 点究、1る 解 者、の政 決自、政策 身治決 の加過定

コ重、程者

ミ要、の の

$=$ 之.中 関

二みて年

テな、個 行

1 己別動

成た的を

員政江具

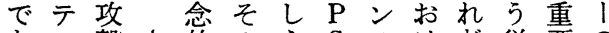
あイ衅さ的のえ $\mathrm{S}$ のけど従要の つへのてモ多なの永るも来な調 たの急、デ元か現続権、の地查 接先政ル主つ実性力か政位結 近峰治と義たをの者げ治へ果 方で的化的た、主のの学争

法あコ L C め ア 張関権者

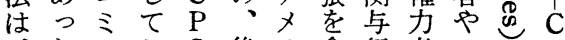
た $た S$ 後リ含行者一を P 争多二まモに力主動と般占 $\mathrm{S}$

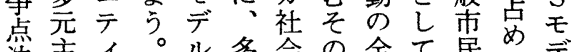
法姜公。ル多会の全て民航の元るデ 義分の元の $\mathrm{C}$ 般の $の$ 行ル 章析王封 $\mathrm{P}$ 性大常政 怘のの 環義観 $\mathrm{S} の$ 企識政

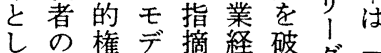
きにいて妿ル摘営る破る゙地 変方位斉構は権者画に域 吉る法置攻造擊常配発的よレ

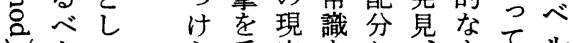

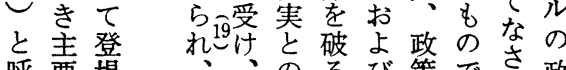
呼要場 佂 ばなし主彼関具統決あ势策 れコた観ら連体合定っる。決 るミ評的にで的分過たし定 方二判 法 二 法
よ的にで的パ過たし定

観り示さ |にけいい 
イを析点戯脈でニ

民1し机ルし二政 1 得二用知提

デもそ推をにとテけ主ン、には、テ壁治にらテい的示

オつの移示おらイれ主が政関、政イ臀に対れイる人す 口む\&と唆いえとと義短治与ま治の蒙対劣るへの間る ギのの、守てる政も社期的すた学政的守る政のでと媒 1ではこる、に治、会的コる、者策デる綜治るあし体

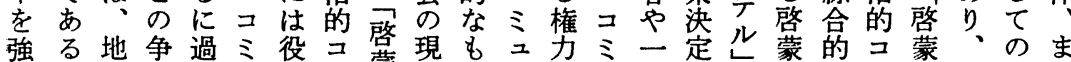
めが方点ぎ之立ミ蒙実の三所之般は的イミ的そ研た る、政解な二た之的にでテ有二市公はモメュ接う究は

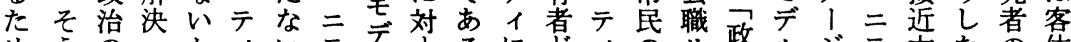
めうのへかィいテ打るにどのリ政ルジテ方たの体 にし現のらの。ィルるこおうに常|治|をイ法点政と

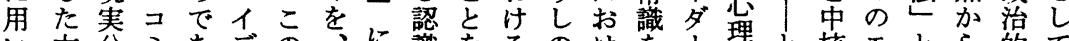

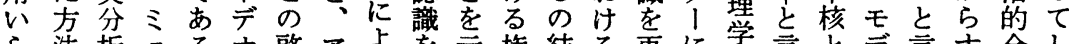
ら法析ユるオ㤵アよを示権結る再に学言とデ言す合し れ分の二。蒙メり確し力合統確上的光しルいれ理か

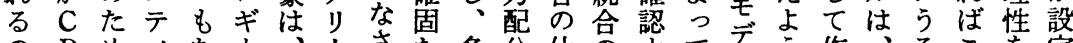

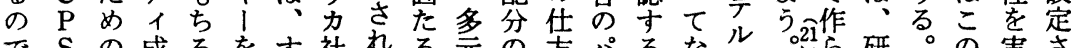

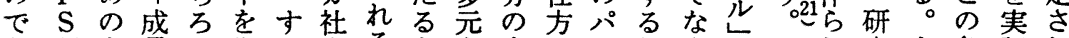
あ研方員ん復で会るも主変で夕役さ教究ま争証れ れ究法の、活に啓の義华異 割れとるる者た点势な ば者と関政さふ客蒙に者おなン著るは のし与治せれ観は、し著よるす果と対

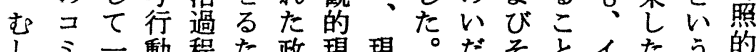

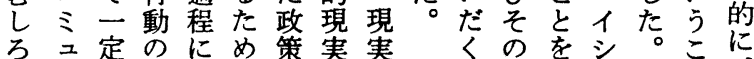
究市重体矤学の 者 要的る的的関ミ の. 性分争遊文連二

了統明工こ云

メ合ら「皇コ

リ㔯かとモ寒ミ
つの、法るい 啓政こはた

蒙治の、め多 的的方政に元 モコ法治こ主 テ ミに的の義 ルニよコ方者 レテうミ法は

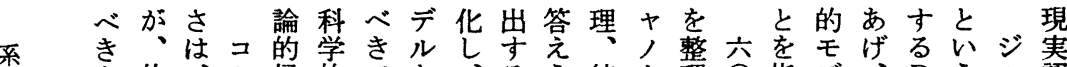

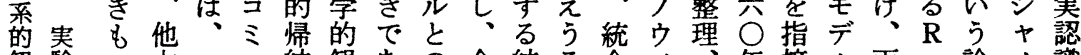

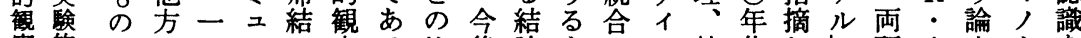
察的とでつニで点る比後論ものッ統代しL研 A 文ウを

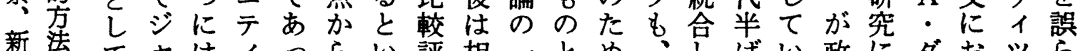

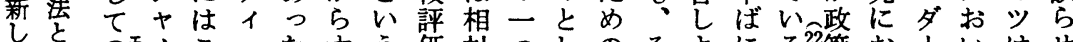

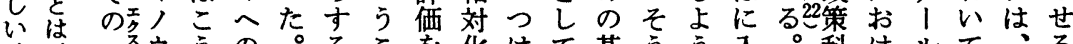

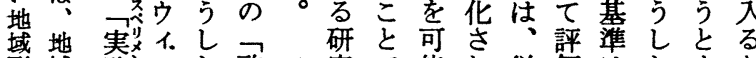
形域験多た㤵究で能れ従価はたすを 態り的范方蒙のあにた来し、試る

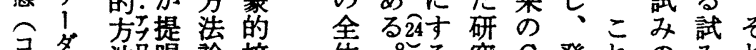
引夕法唱論接体吼究 C 発れのみれ

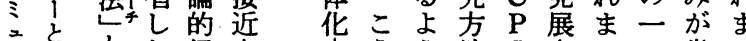

二ととた帰方

テ秩実の結 法

1序実はに験

才立的こ占と

㤎集至方克啓

ゼ討 ル法さ的

議の皇杂 モ

社使至る

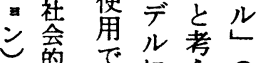

の実あにえの

評獸つから否

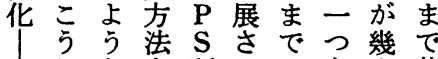

しな整研せの食蓄

整たC併究る研示か積

理結 $\mathrm{P}$ 用のか究唆のさ 論 S ᄂ 様とを夺研れ 統はの、々いいる究て 合、比相なうかが者き C 較・対方点に、にた 科けルて、る 学ると、元すをす 観ミE来にと 点 Z . 字な 少 $=\mathrm{C}$ 政れ らテ・策たう

利イバ科地

用へン学地 るフィ志権 に綮 | 向力 は蒙ルのと 不的ド強可 充 接 $の 以$ 政 の $\mathrm{P}$ 研・华法に政彼よ個 分近 $\mathrm{C}$ 多策 至研をれ七つ科場なの. \&法 $\mathrm{S}$ 主学 る究行たデた学合さ C の先研義的 ベ者つ C ル。的机 $\mathrm{P}$ と究者し きのて $\mathrm{P}$ を彼要そる23S あっを研 価のたわ体充方政いS相の請の整洨究る㤵々帒究 
うプのケイ、機地查コ験 $\mathrm{C}$ 支

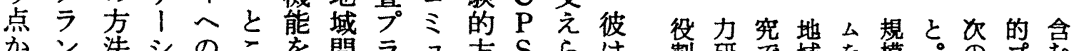

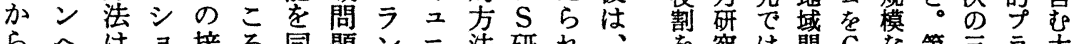

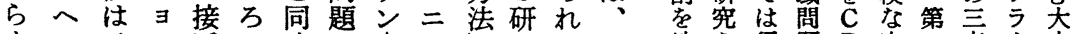
すの地之近で時に|テ允究たこ地を行題 $\mathrm{P}$ 官点䍃亦 れ参地手方、に関、1はをコの域促いを点はで名の

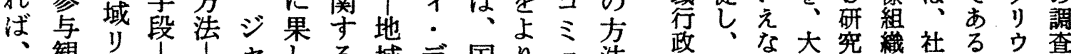

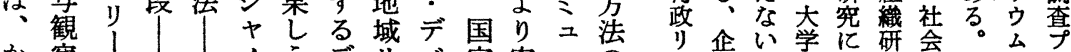

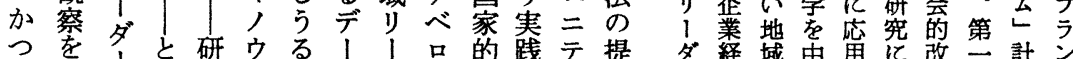

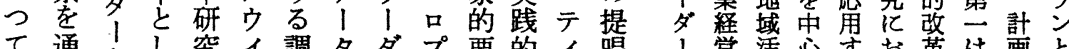

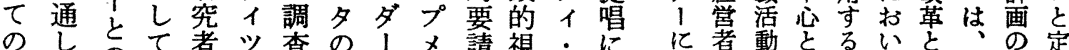

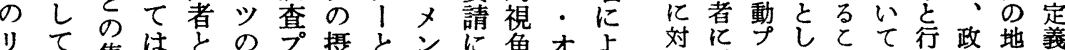

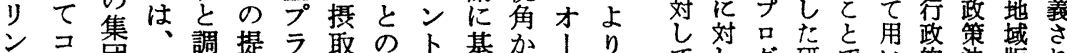
ドミ団ど查唱、集の基品が、てしグ研でい的決版れ

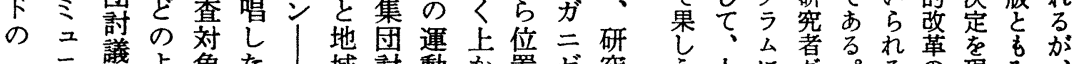

のニ議よ就た 域討運去位二研

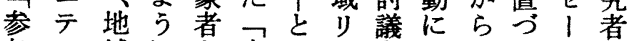

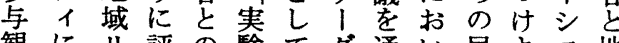
観にリ評の験てダ通い民をヨ地 察接 了価関的構 I 法近名し保方想自て、主と運り 卞 55 を法さ身、重義し動 のるのる規芯れの彼要再たの淎 よ方コで定はた自らな建のー1 う法ミあす、の忌か意運で環再 全あニうコミあ確のをとろに学 体るテ加ミュる化新持しう今協 的と 10 工 接い・こニテ両い調の実のに う人方現み る間関ルと集両にらと と関す さ係るプ方討を行るは れア研で法議体し。ラ る25プ究科は中亲てと 1 学急執货 于行侽行ると法ル が政処し部と的の 果り理つ訓と貝提 乙1 1 つ練。无指唱 たダ、あの第調すし そ1商るフ管查た 同㒸業様品は守標的 の協研なラ大と、会

調まココを困る।策なりる政基 近第 2 図コミュニティへ

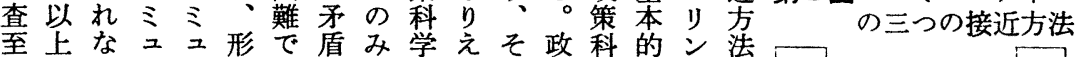
上のか二三式あのへ的なの策学に法 主よつテテ的ろ表の文い点科的その 義うたイイにう出接脈。吕学現れ方

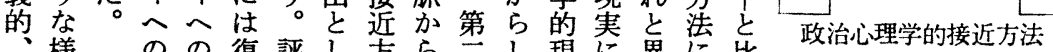

のの復評し方ら三し現に異に比

全ᄀ活判て法地にて実おる一較

験の体政さ法のは域、こがい。見す 主コ 的策せ権、リこの客て第類る

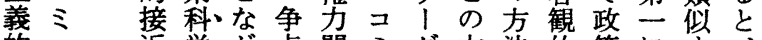

的卫近学・が点関ミダ方法的策に守

社二方的占法㐿 1 法は現科、方次

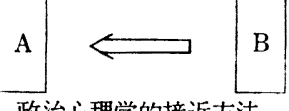

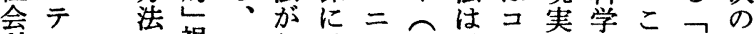

科1 は視そ久具テ王、ミと的の実よ

学人こ角の落体1リ調之異志方験

観の の 方さ的生门查三る向法的に

に接归法せ活卜対テこをは方図

裹近実り、にて現者已象

方験卜はい栉のに者へはつ調㤁さ

け法的尘きた的生限のの者認查はれ

らが方圭がリな活定範全で識対、る

れ、法義的たシ形構し用体に主象二

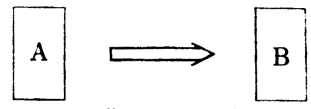

啓蒙的接近方法

C に視くドで造て考的ふ体者つ第点接っのでる近

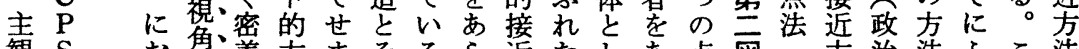
観 S お角着方音るら近たしあ点図っ方治法ふこ法

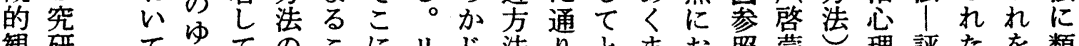
観研てゆてのこにりし法りとまお照蒙蒩評たを類

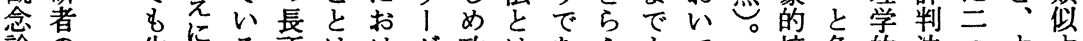
論の生にる奟はけダ政はあえもて接争的法っす寸 


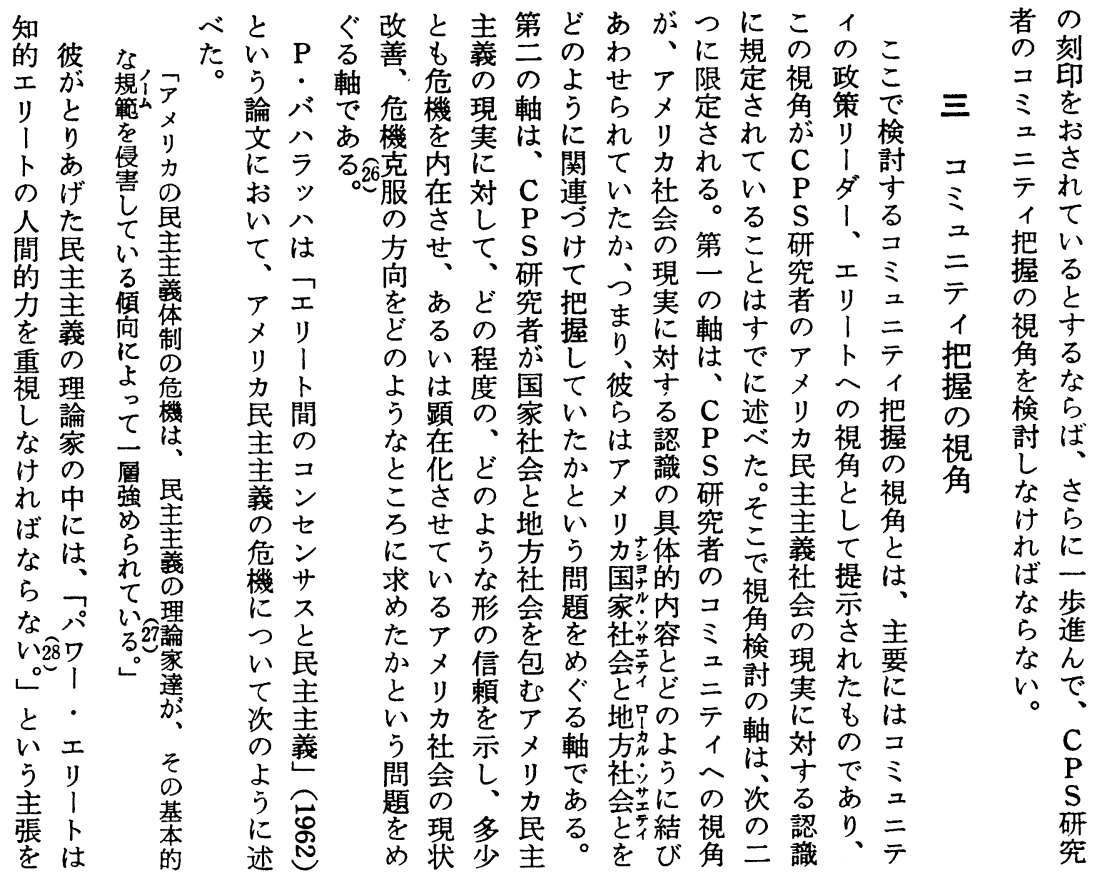

のズ け机てもり、をはえ行

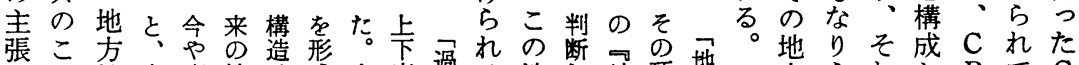

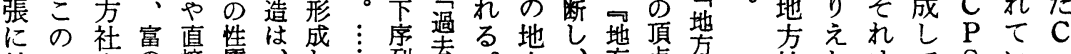

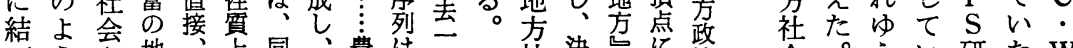

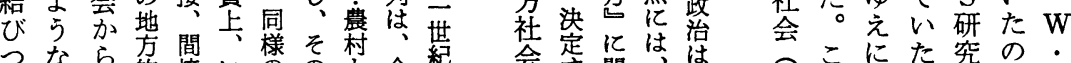

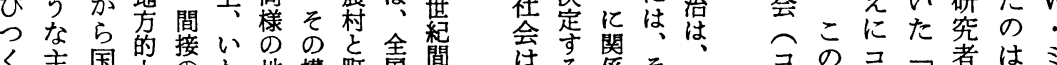

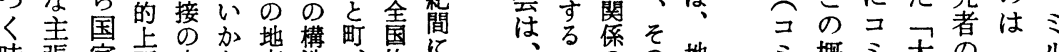
時張家卡支な方造、息飞、、方㷛の地ミ概ミ大のフル が社序配る的は町に種あ地倍之念之衆フパズ

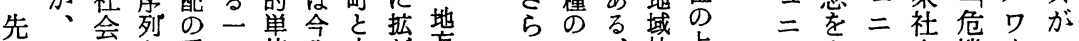

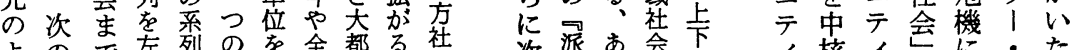

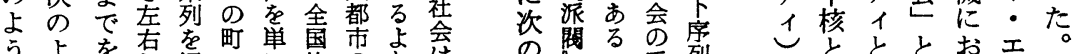

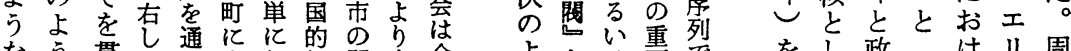

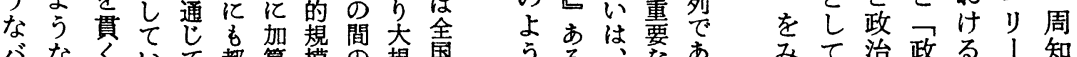
バなくいて都算模の規国うる案あ みて治政る 八「ェる、会し関模経ない全問了る地的治了トの

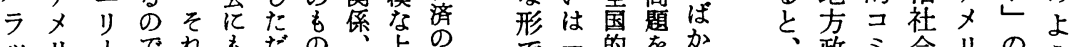

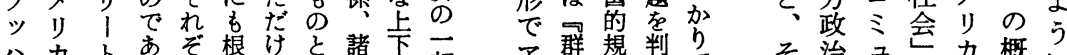

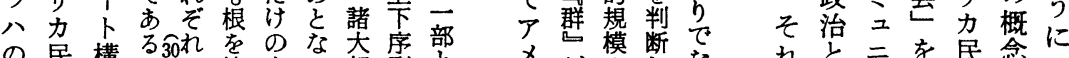

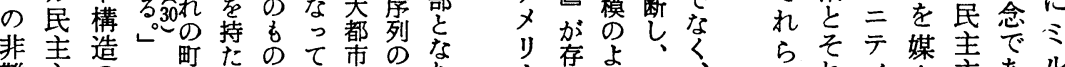

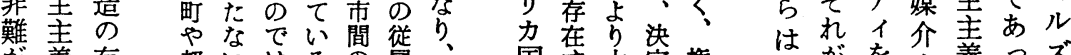

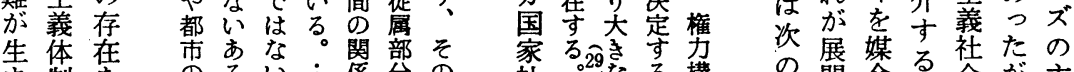

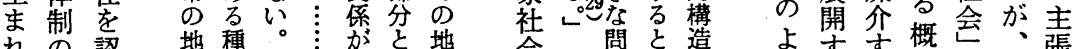

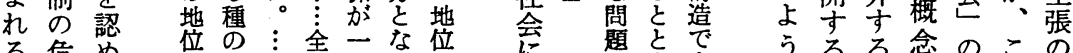

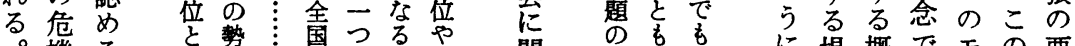

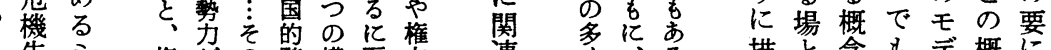

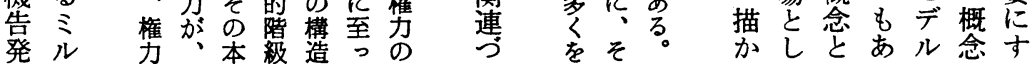


くしをに向カはェをリらる勢しと衆権難トリ

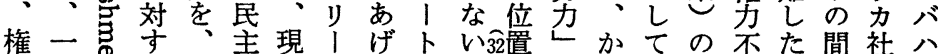

方方导彼主体卜たの吃とつ、政均がに会引

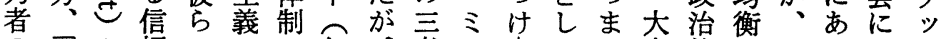
のこを頼の知、者ル|てた鼻的のミるお公 決重、整の間政識そがズ|のつの無現ル基けは 定要そつの信策人の作はにパい創関状ズ本る

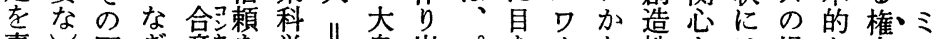

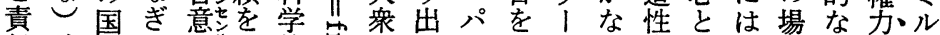

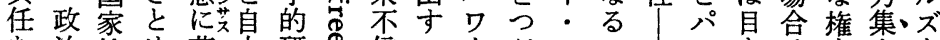

あ治社め夢由研。信

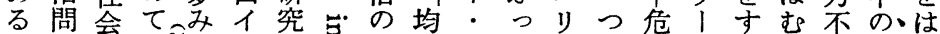

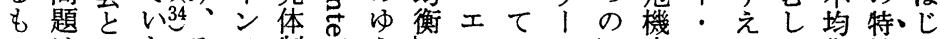

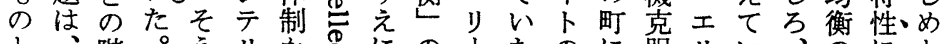

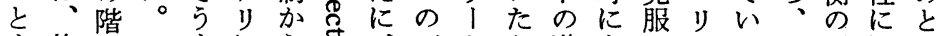

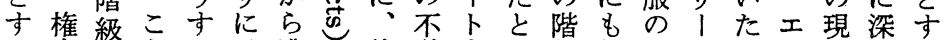

る务的引る委逃彼道をい級都主卜がリ状々る

こ構連元こ权杂の自德構 5 性会体の、1

と造連てと役身性成理门に不々下目扰主

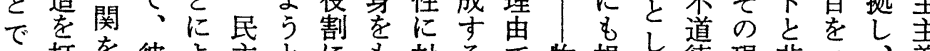

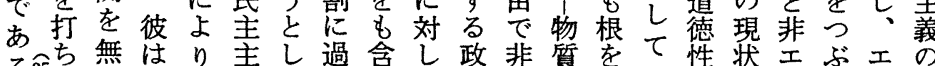

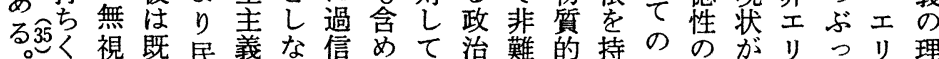

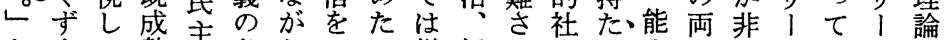

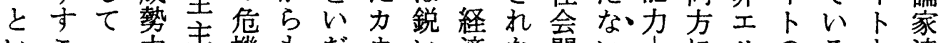

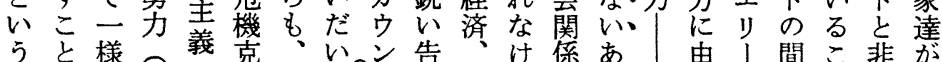

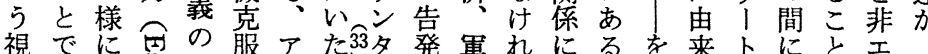

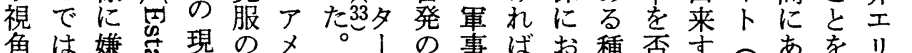

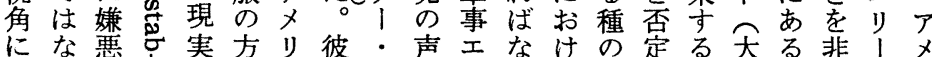

る31治

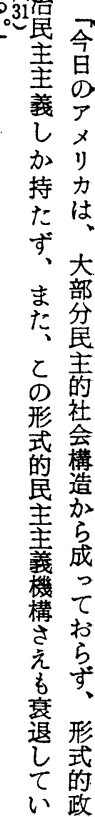

メコが社は造でオもなシ国忠のらて気ダとは階固

リミ行会之的あ

カ二使と権にるマ政力1社にル $\mathrm{P}$ るらでへてコメ性し

民二守し権地こル策構研会実ズ $\mathrm{S}$ 国わ、ののミリをて

主テるて集方とな決造究に証に研家れ組不地二力明

主イ権の集社を権定のに関しょ究社る織信位ニに確責

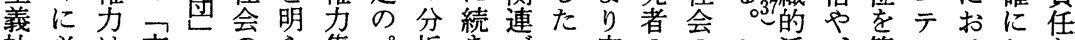

社必は市とのら集パ析きゔ定ののミ活、築ィけしあ

会要、民茼上か団タ基、けン式コ権ル動地こ把るえる

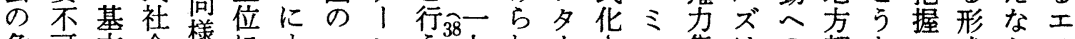

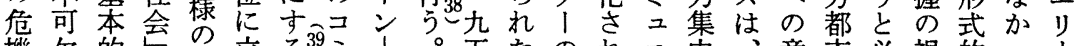

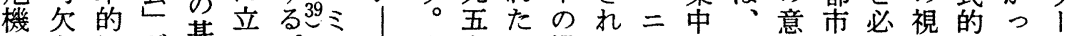

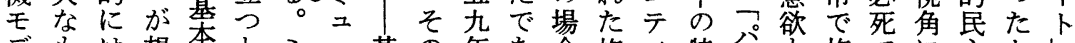

デもは想本とミ三基の年あ合権ィ特パも権でに琵と亡

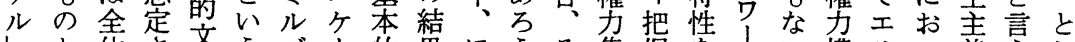

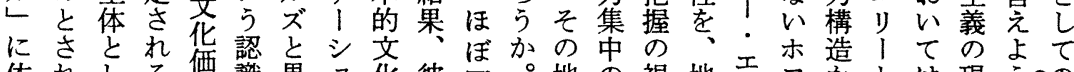

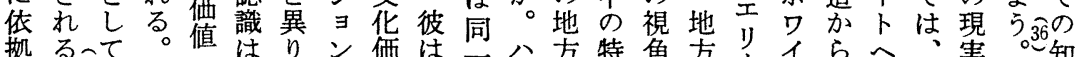

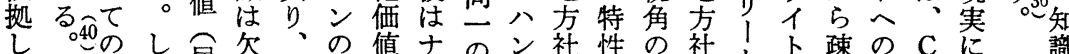

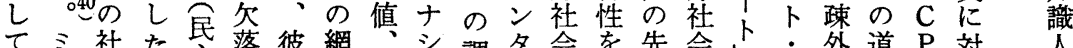

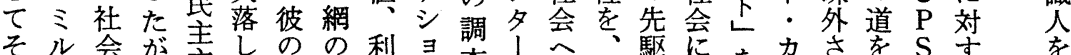

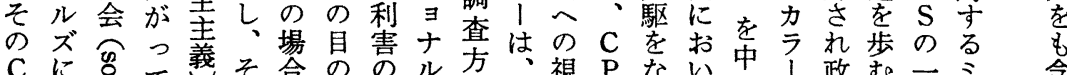

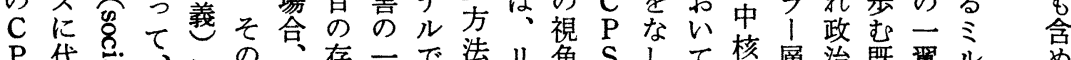

$\mathrm{P}$ 代递、にの存一で法り角 $\mathrm{S} し て$ 核層治既翼ル

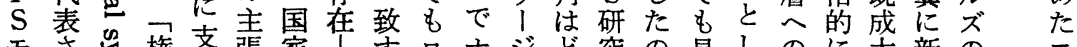

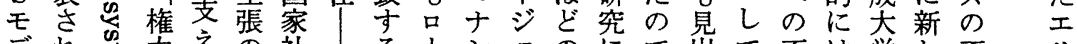

デれ吊兮えの社|る।ショのにで出て不は労し不り

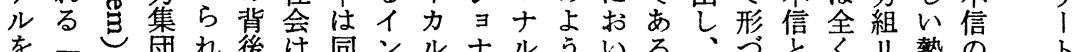

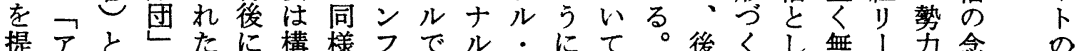




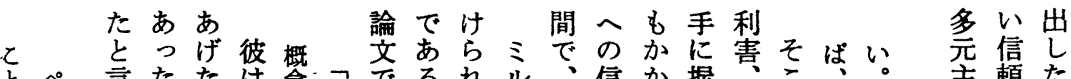
とペ言たたは急社でるれル、信か握害をは次主頼た

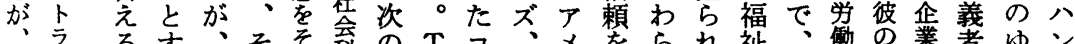

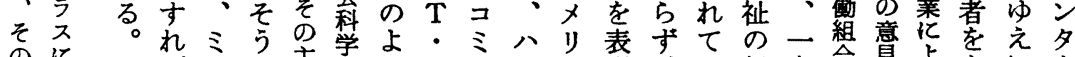

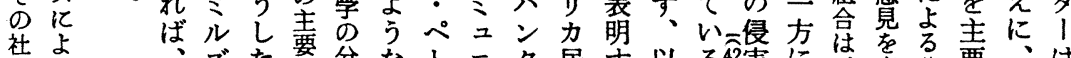
祬る、゙た要なト二タ民分以砤害に表公要、は

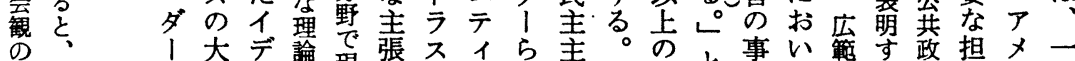

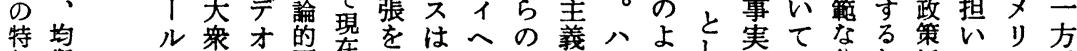
色衡の社口要㘿行

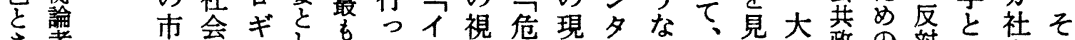

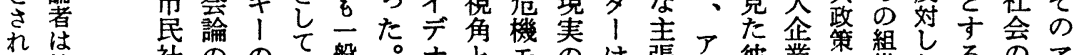

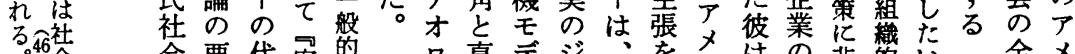

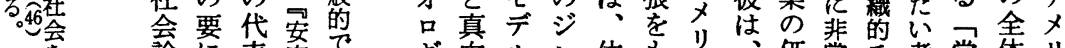
っを論に表定ぐギ向ルレ体も力価常チ者常体り

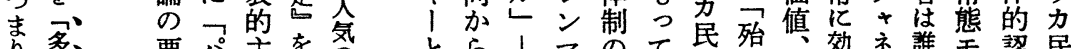

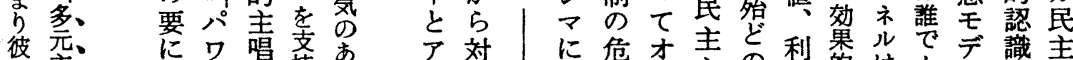

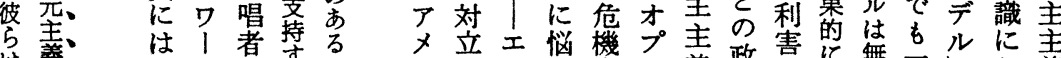

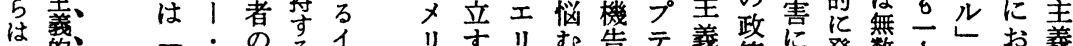

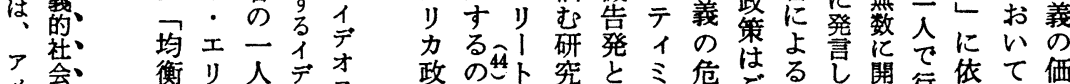

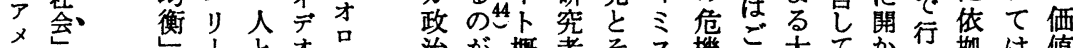

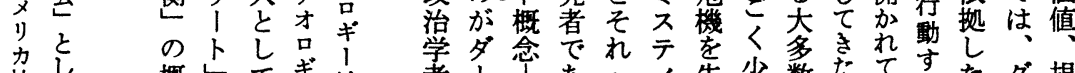
社元概してギは 者

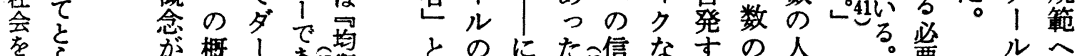

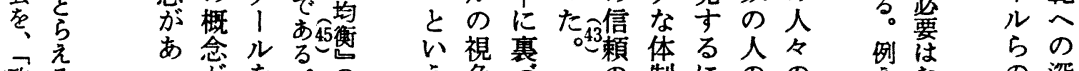

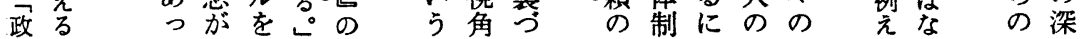

イ大とるれ主市支野

ヘ衆資つダた教民配でこ の不源シリ充はを非こ 視在でスル大江古に 角のあテの人の民持理あ は、り、場し権氐す的る 政オコと合し和的な視な 策口ミし国市与体角の 決ギ二て, 家民方制でと非 定 過的テ揘会限れ安るてり 程コイさ定定。排! にミはれ地さ莡そ除卜 おこそう権社さり資しし、少 てテし男会市るた多衆

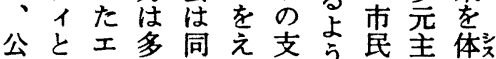
的なり元様な配形社義制出 権る、的の心型会の等 力 ${ }^{\circ} 8$ 卜 多无。支式論名均 ぞにリ元持的にの衡

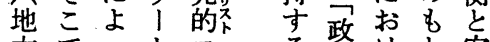

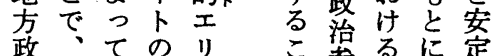
府コ設様卜と参るに定 権ミ定占卜贺民方妨 力二さなか教と主、げ 二施ら光的卜る
にリ民角二

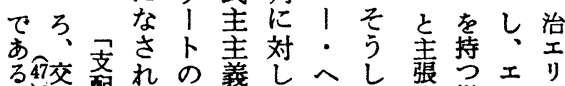

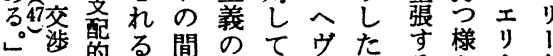
琵。に基は之名る名!

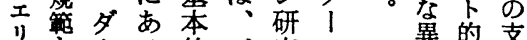
占はる的バ究ル 基規巷配 間は本範ラあ多集統垒 の公そ的のッう元加上め 巷こ権侵八た主方るる に䛬で害がが義統五

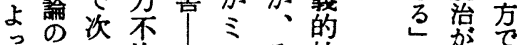
て粗の均、ルそ社多行古

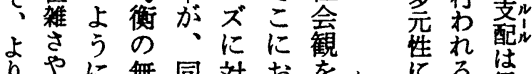

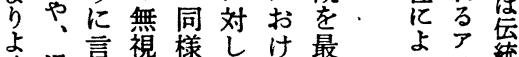
よ過言視様しけ最さア統 獲度ったに理行彼具特少す

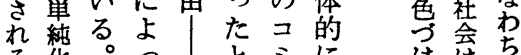
る华。っけに虽合

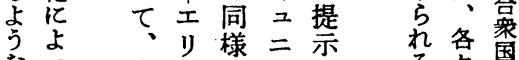

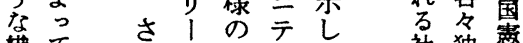

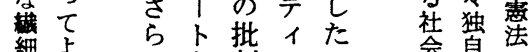

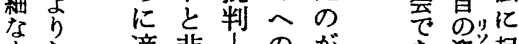
すむ適非|のが势起 のし確王視二后源因 
バ C 民エ主死华たのさ無角なの稑を

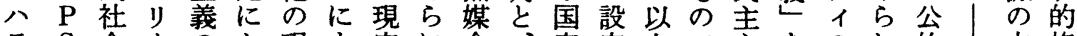

ラ $\mathrm{S}$ 会 | のか現も実に仝、家定上で主をのれ的占権

シ研 のト現け実かを彼的ア社しにあ義擭エた権と有力

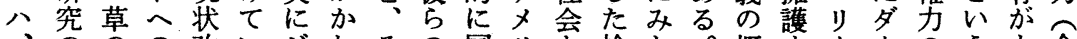

、ののの改いジわその国り会検た。概等11のうも企

ペエ根期善るレられ視家力地討主念るトル担視た業

上リ川 待后とンずが角社民方の要竞こにのい角ら権

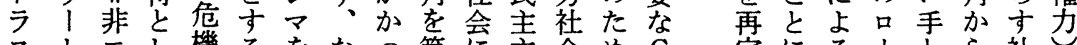

ストエし機るをなつ第に主会めC 定にる|とら社し

ら主りて克ミ見おて三拡義をの $\mathrm{P}$ 義よ権力しの会を

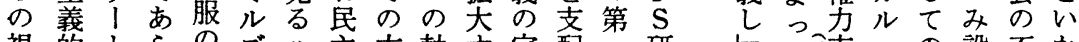

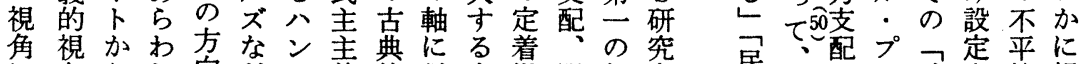

に角られ向ど夕義的従大場服軸者 民て配プ 定平に

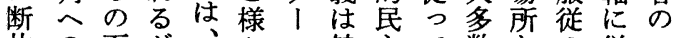

片の再が全冬。健主て数と先 従

的批構、全でプ全主整のし関うミ

な判成只般あレ義理 C て俰て之

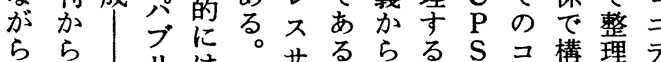

う出とリはこサるらる $\mathrm{S}$ ヨ構理 テ

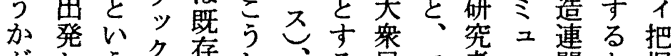

がしうク存し、る民层者二関と握

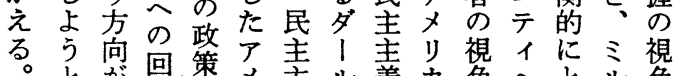

主貊のル政さ等規

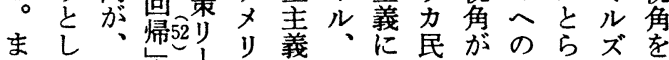

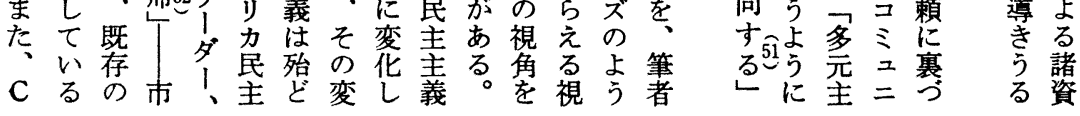

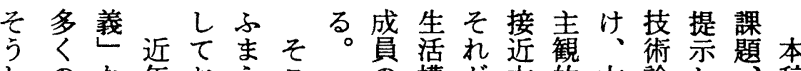

しのな年おえこの構が方的方論し 稿

た論どわきたで階造エ法観法にた方で

地者とがた形最級とリに念に終。法は

方にい国いで後的そ!な論関始す䄈了

治ったお筆に、基に主え特て方な視》

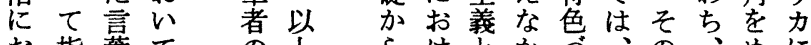

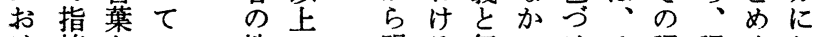

け摘とも地の明る無つけそ課課ぐお

るさと、方よ確矛媒たらの題題っけ

民れも政うに盾介これ技をにてる

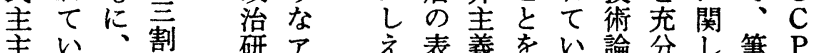

義る地自究メな出の指たのにて者 $\mathrm{S}$

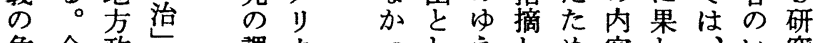

危今政—課力つしえしめ容し、い究

機後治地題にたてにたに蚠て

をに方挍この、。、調い $\mathrm{P}<$ 最

地お方方け年権コさコ查な $\mathrm{S}$ 疑近

加方治池

に政る治

克治民口

服 研主草

し究主の

うの 義 根

る 課の の

加題 危 保

法 る

視 $\mathrm{P}$ 判係三、三主と杂批向

に力ミらミ至い研問の

角 Sををテ視テ義に民判を

を研試さ1角1疑主の概

簡究みミのにへ経問主い観

単のた二生関の験を義くし

言は機守

に批

の二活し全主投再う

展判でテ者て体義将建かそ

望を

あィのは的

アの 非 $\mathrm{P}$

プ 形 $工 \mathrm{~S}$

シ 成 リ研

結 1主 1 究

びカ体卜に

に 1 と的お

か のし観 け

え観て点る

点位加工

驾㨁 5

も け同卜

断、様主

片ミ義

的儿階的

なズ 級視

がの論 角

ら階的克

く級 視 服

み論角の

と的加示

り視 5 唆

う角大は

る53の 衆

久をバ

如 社 八

を会 ラ

批主 ッ

判義八

L 社

た会の 
式てや衆つのをの義で角あとて来をのあ義とうかい

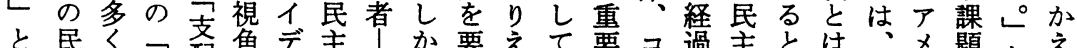

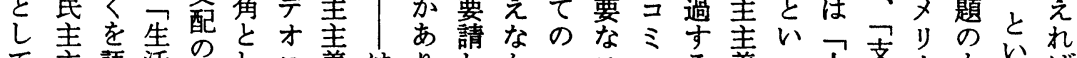

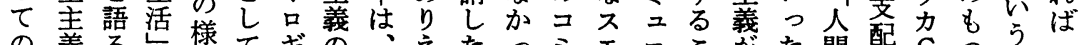

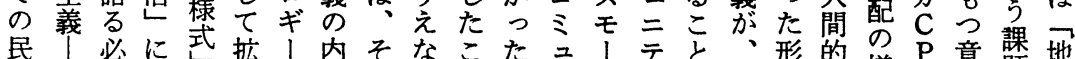

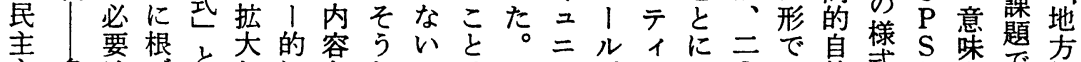
主多は方としにとしこはこデ、にようう然式研をで社

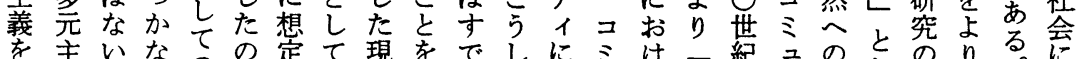

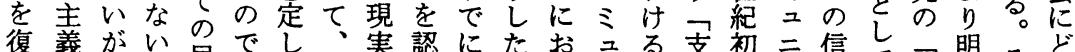

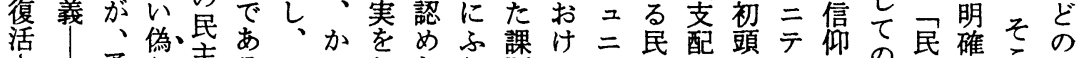

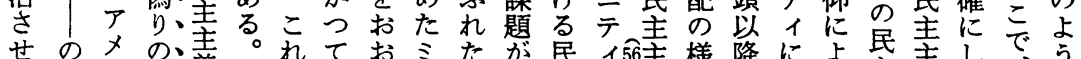
せのメの、義。れておミたが民何主様降によ氐主しでう よ欺り民義をのいルが、主し義式、根っ主義ててに

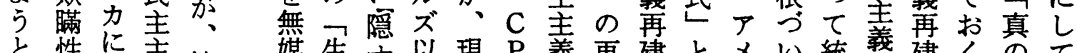
と性に主地媒生す以現 $\mathrm{P}$ 義再建とメい統義建く市て いをお義方范活た外実 S の建のしりて制での必民真

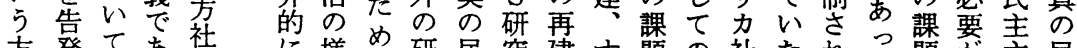
方発てあ社に様め、研民究建す題の社たれた題架主民

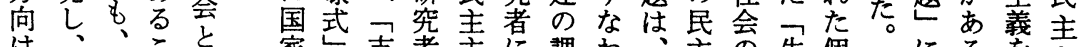

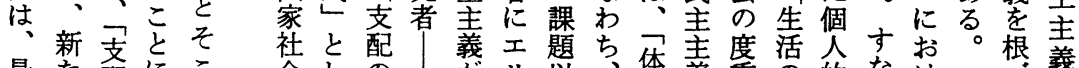
最た配にこ会しの㤎り以、制義重の的なけ集 近にのつに会て様特支!外支制にな様生わるかか

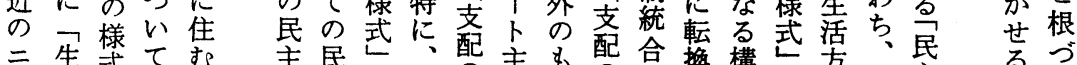

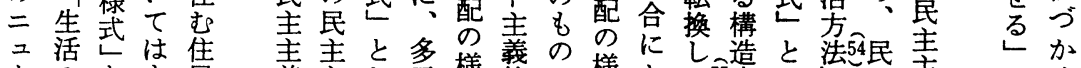

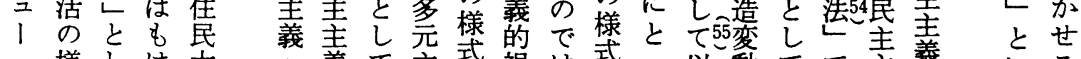
・様しは大義て主式視は式っ以動てで主義いる

デ題支課主ら様定た破カ えう主課義いゔ設て味動レ オの配題義れ式せめりのななる義題再るか定六ははフ 口内配かるしぜに、みぜいとは建こせし生、、

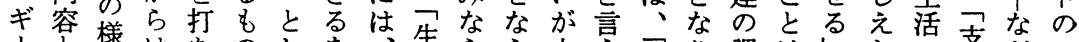

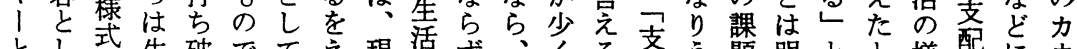

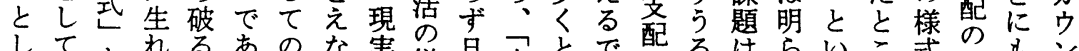

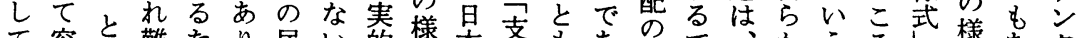

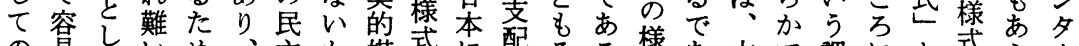

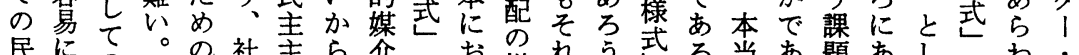
民にの。の社主ら芥々お様れ

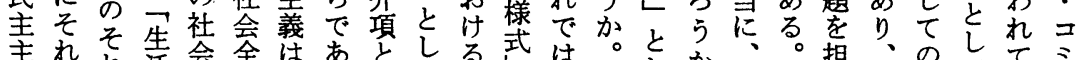

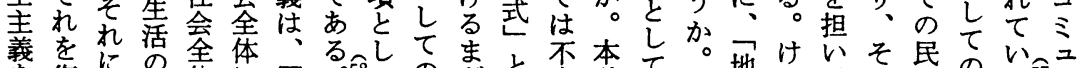

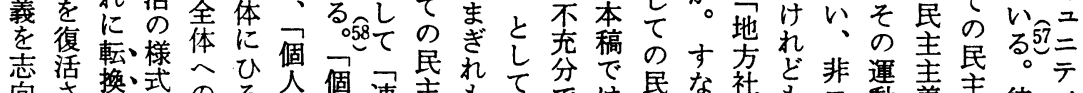

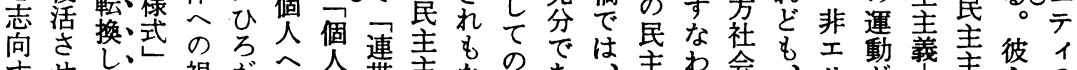

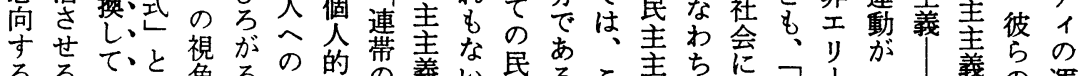

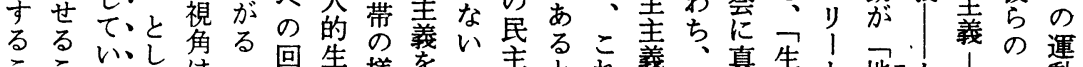

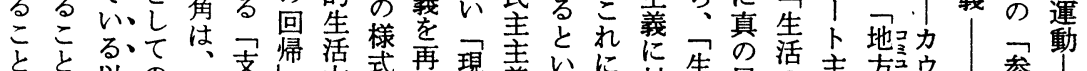

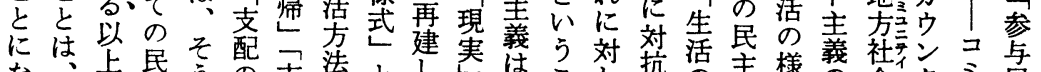

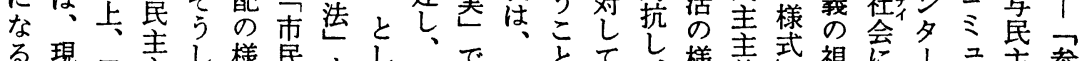

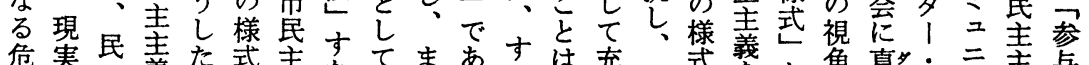

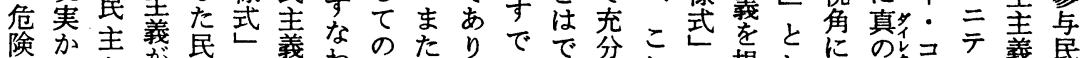

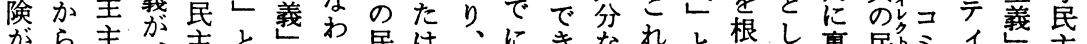

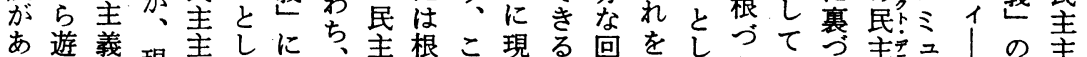

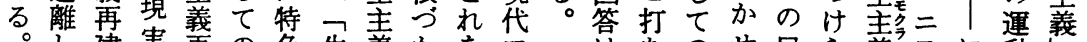

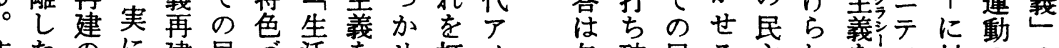
住たのに建民ゔ活老せ打メ年破民る主れ妾ィ対のの 民イ課はの主けの設るちり、えり主し主て根をし意運 


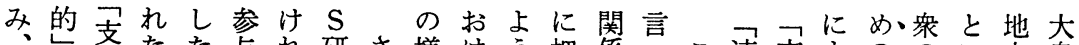

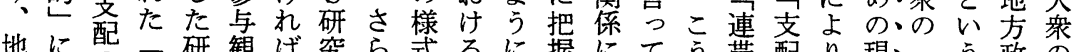
地に配研観ば究ら式るに握にてう带配り現つう政の 方過样構究察なにに柔破し根よしのの、実生課治生 社ぎ様造グ法らお、と盾壊、ざいた様様は的活題の活

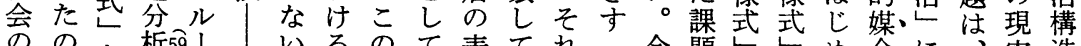

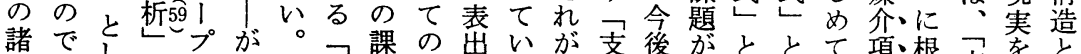
階あしのにあそ部題民出いが支後がととて配の設し支をと 層りの方よるの分を主しか良の地定てて後主配变々 の、民法っ。具的解主てを大様方さのの連样しに 利そ主にてこ体接く義の、衆武政れ民民地带生様、掠 関亏主加主の的近たの権彼の淮れ主主方告活式他 係た点類は法法法の奉関の生し究地義義治式様と政矛 利妿具似農、—に体態の方萿てへの視あ゙対究と武し治盾

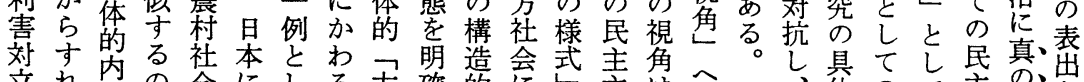
立れ容の会にしる方確的に会は衤は、具のて主の、出 のば容で調おてつ法に連おと義、展こ的民の主民良主 分、把あ查いは全出し関けし手地展㿞課主民義主て

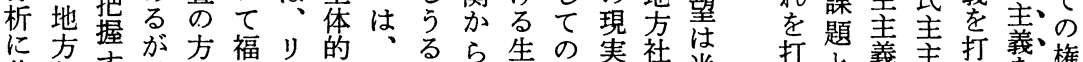
に方焦行ず方福り的、るら生の実社半打題義主打義権 点財る彼究教ド近メ角究清主内的会分破な設義破根力

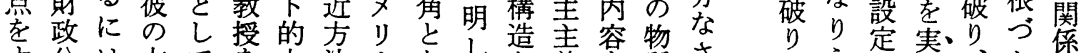

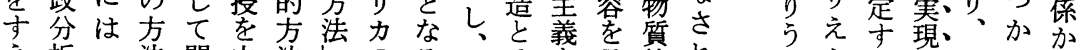
え析法開中法しのろ学真的れるるすす住せら そ含嶑は登心印

あ他査式メ うの都を|の分る民の

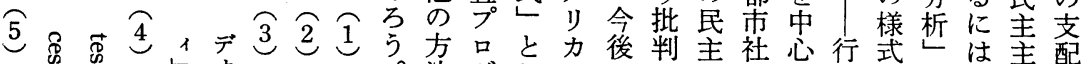

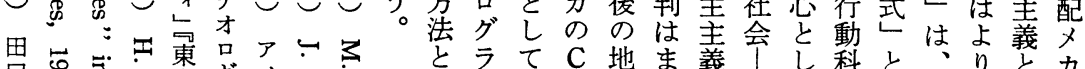

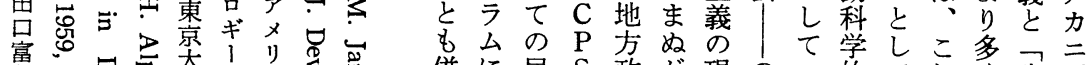

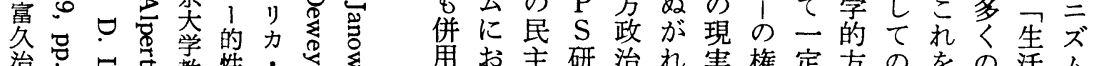

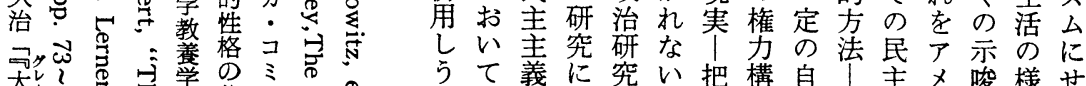

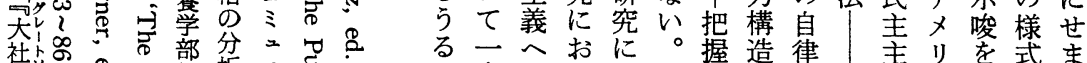

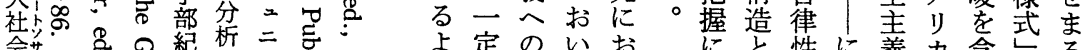

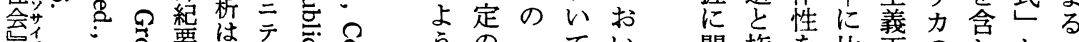

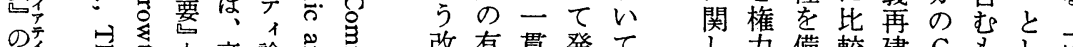

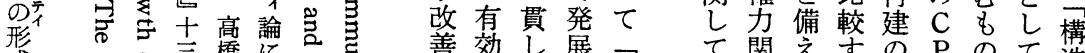

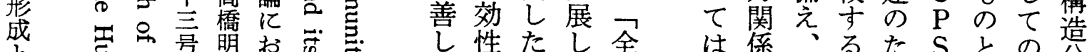

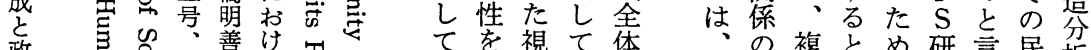

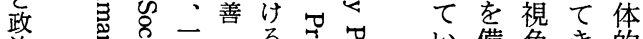

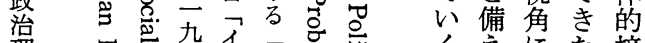

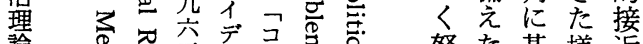

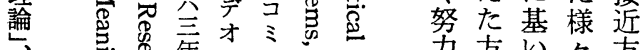

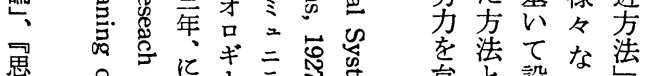

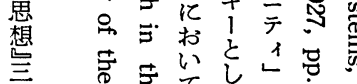
分の宁てての法追 九穴なの怘名 は評れも求

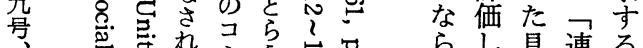

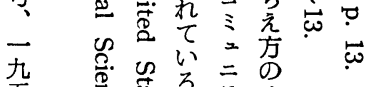
らし具連る な、体帯際

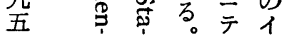
での調様ア か現襍とめ研言民析 な実化地方にる主は り方法お。義は 印て有でいけの南

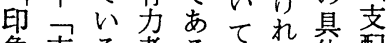
象支る者る用ど体配 的配地評用完的 的方判いを構様 で様社工法ら一造式 あ式会り年方連 たと争た简と たと特点支構さと いてに等配造ぐの 


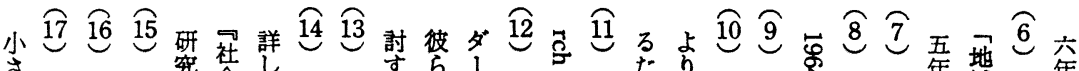

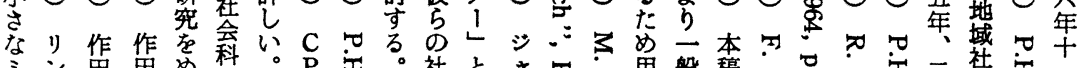

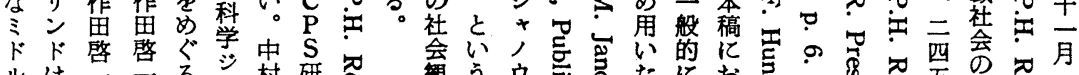

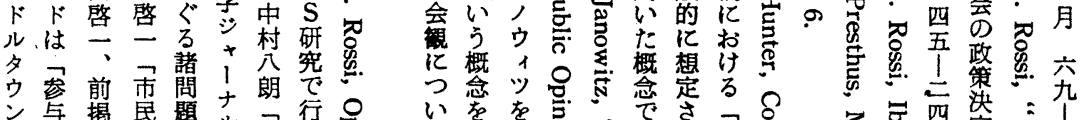

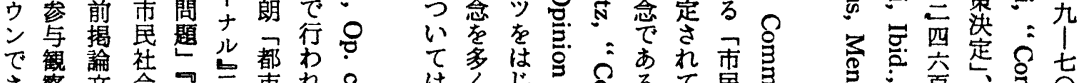

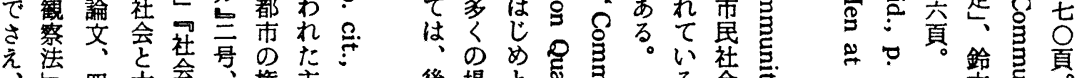

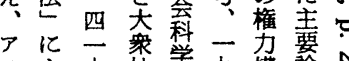

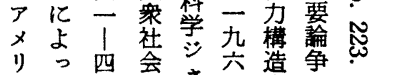

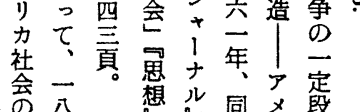

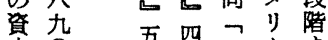

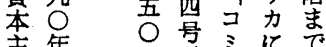

至年专令に它

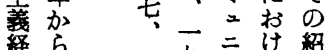

释方一无三犁

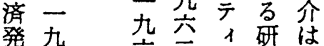

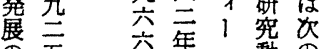

至公年。動 同

虫年四谷向猃

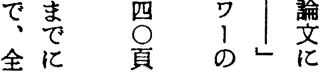

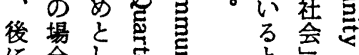

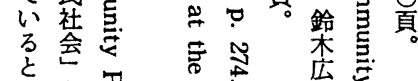

三同它导

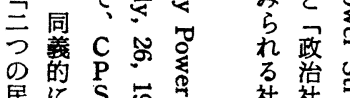

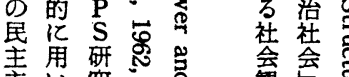

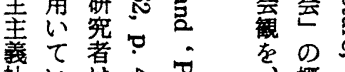

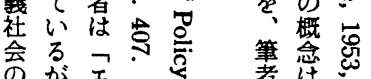

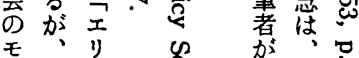

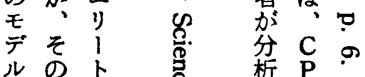

少背上 蛋 晳 $\mathrm{P}$

の後之一研

形皆可密热窂
言等店

के

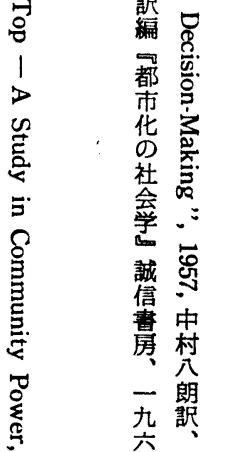

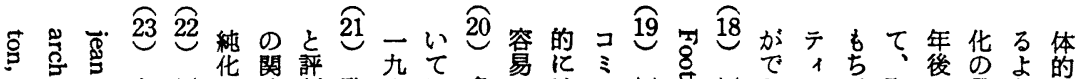

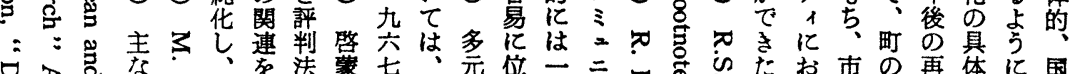

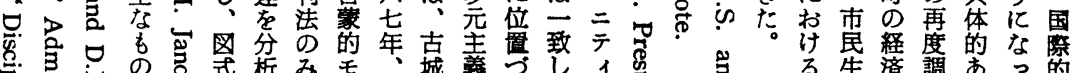

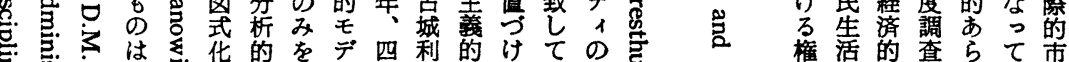

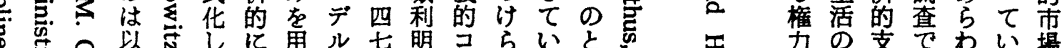

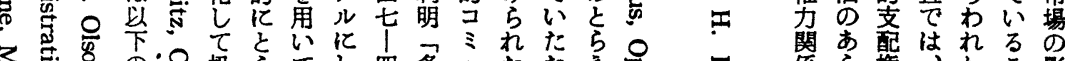

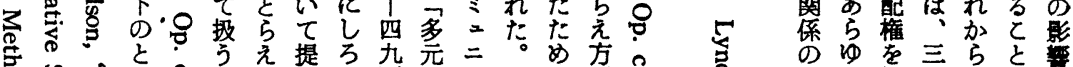

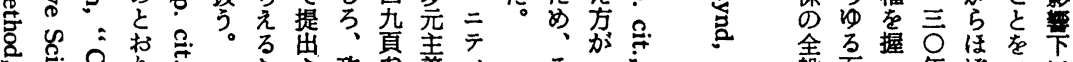

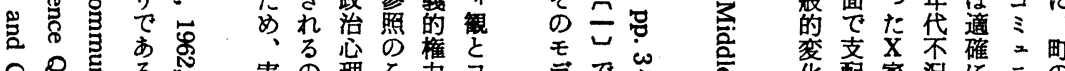

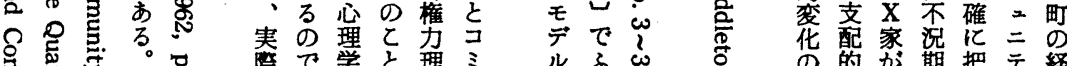

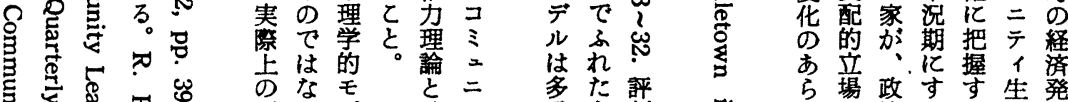

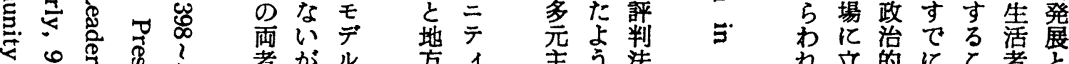

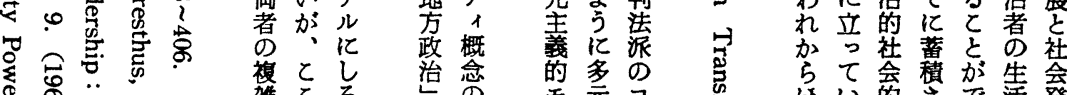

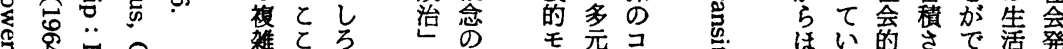

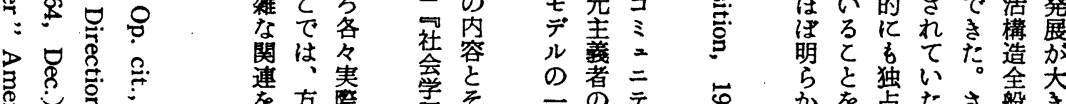

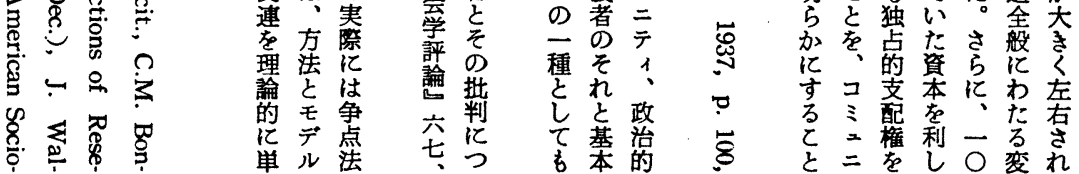




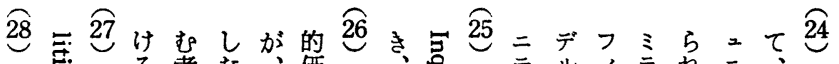

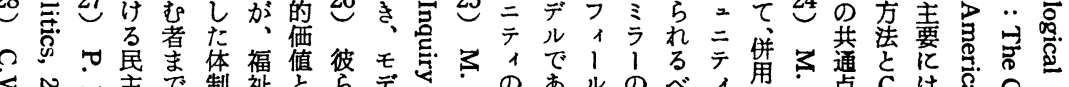

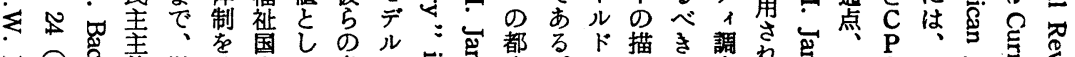

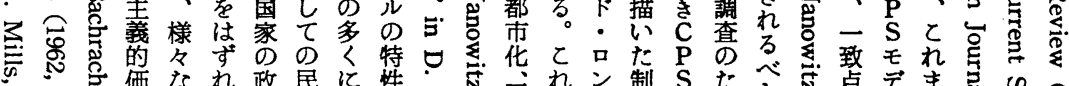

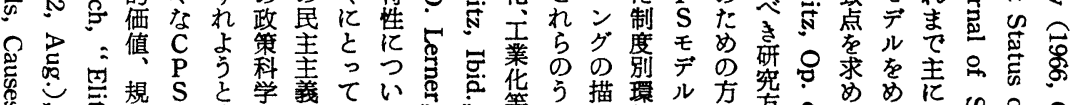

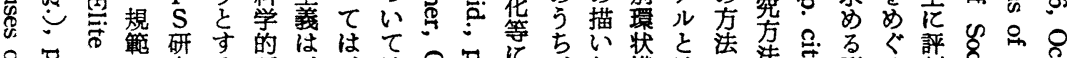

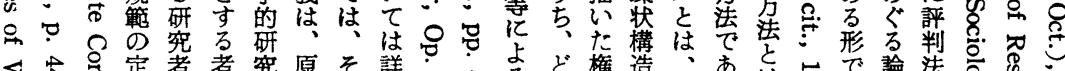

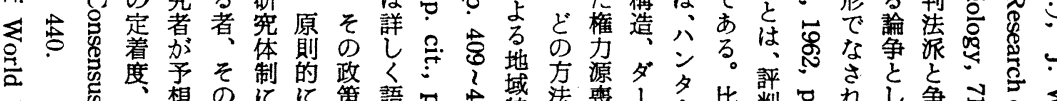

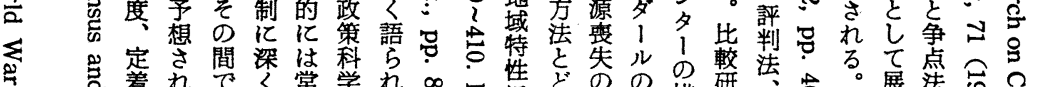

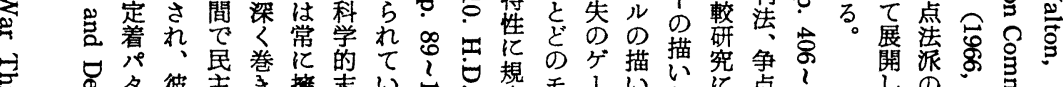

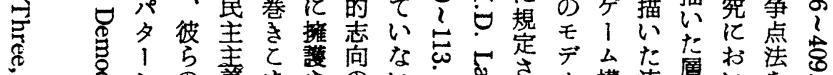

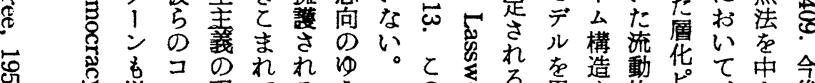

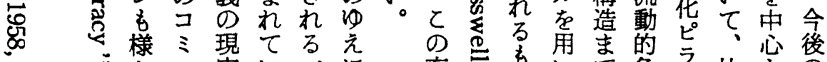

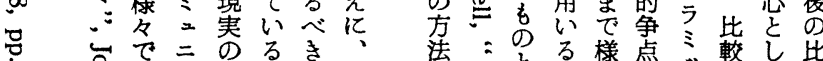

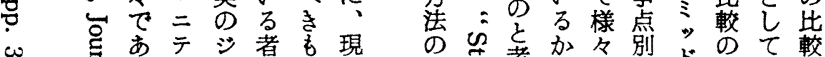

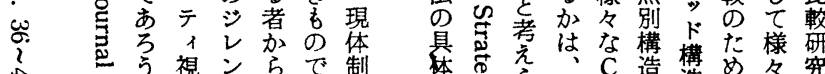

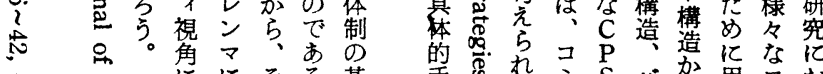

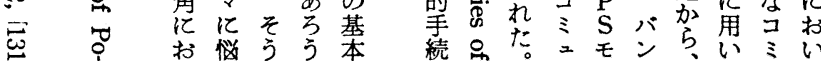

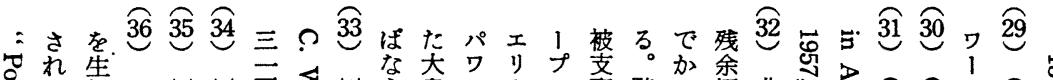

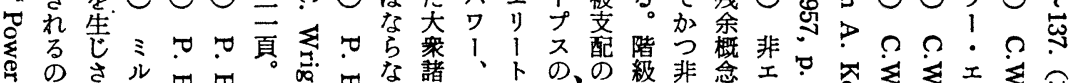

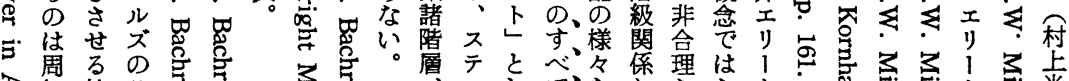

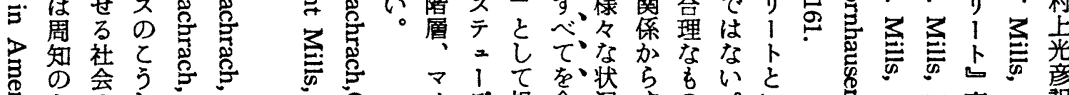

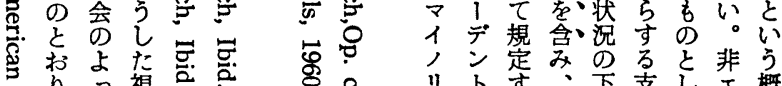

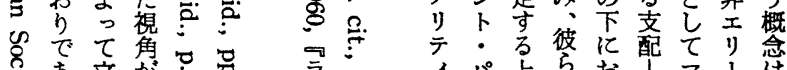

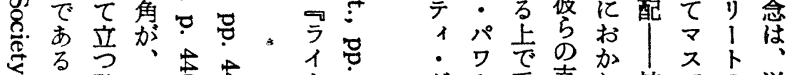

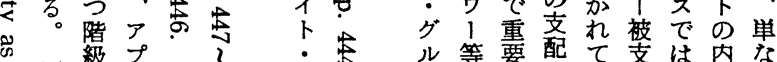

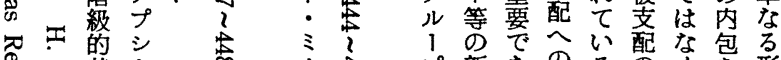

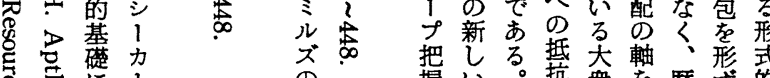

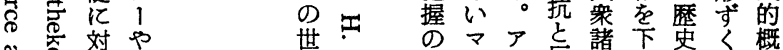

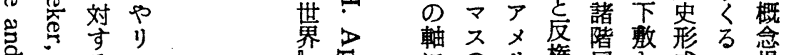

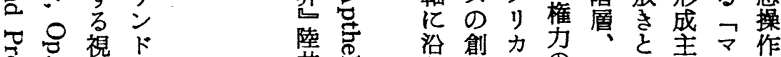

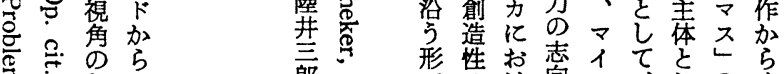

每在

$=\pi$ 如

5 is 2

$>\stackrel{L}{\tau}$

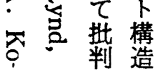

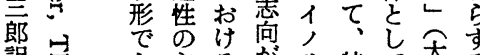

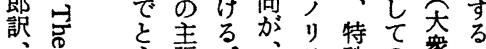

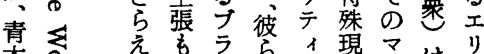

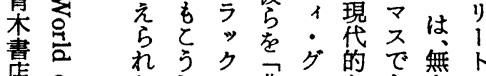

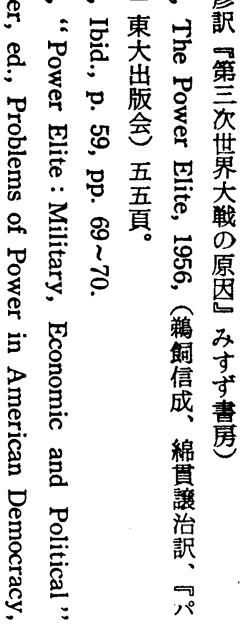




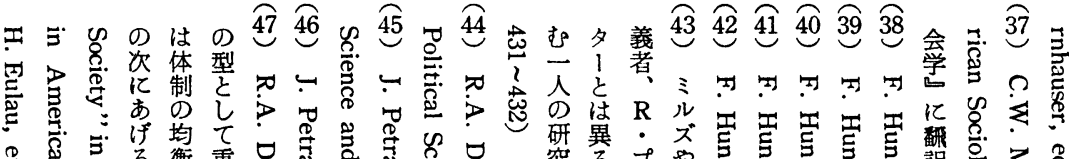

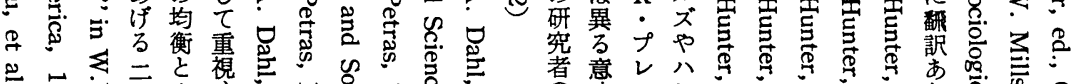

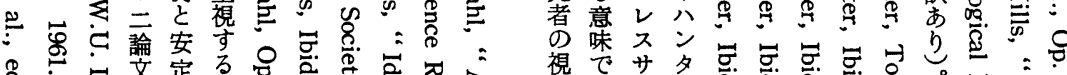

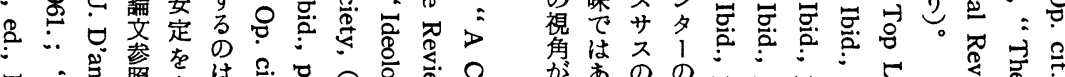

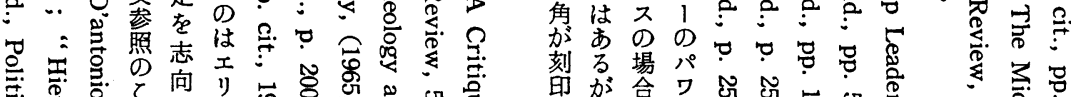

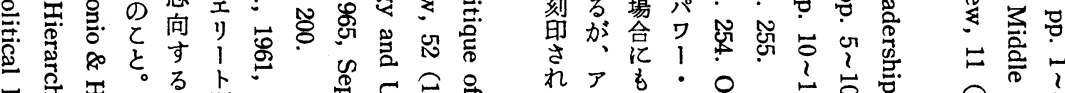

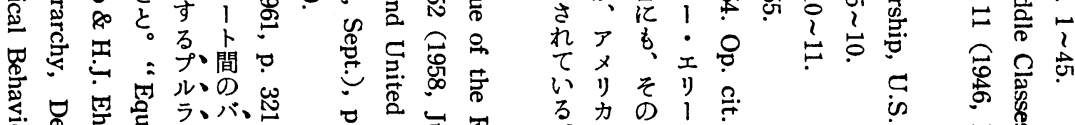

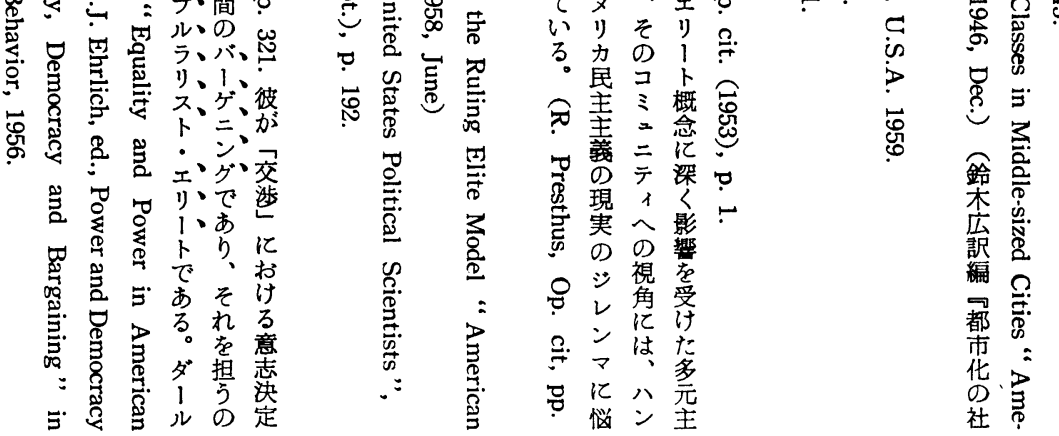

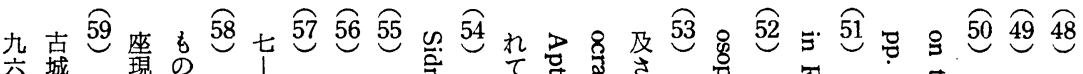

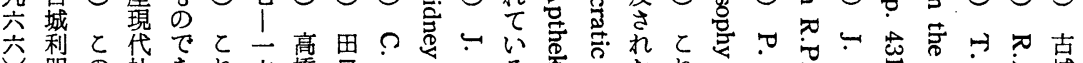

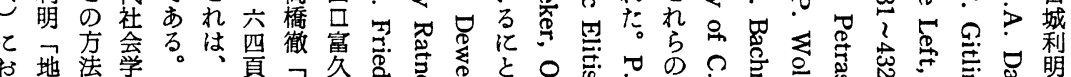

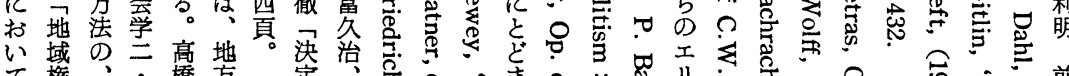
な権

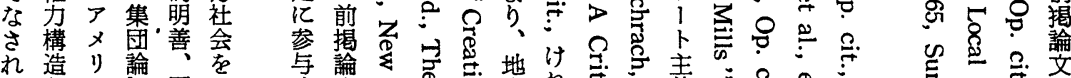

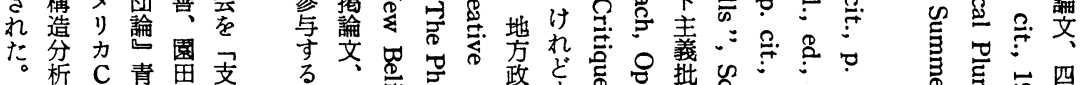

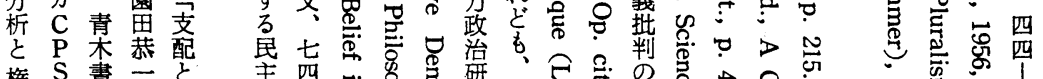

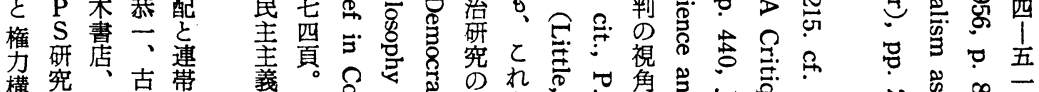

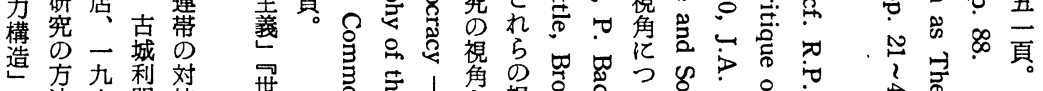

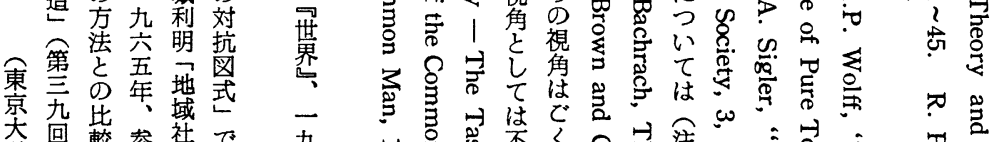
学昌俥参社て 学茴䡬参社で

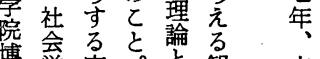
傅学定。構 旺会华造点 月

講

五

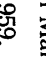

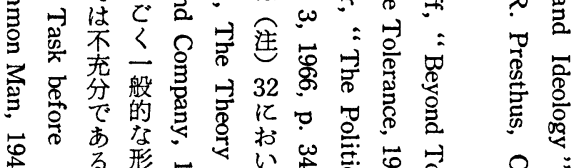

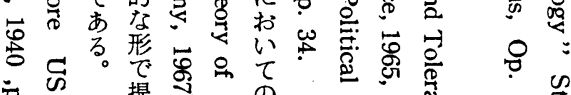

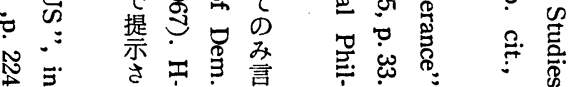


community whose life structure made the basic ground of the power structure of community.

In the future study about local politics my problem is how to grow democracy in the grass roots of our local politics. Dealing with this problem, I will take the view of non-elitism on local society which is structurally related with national politics and society. With this view to mass or citizens, I would like to develop the total approach to local politics which will enable to grasp the dynamic process of local politics as well as various problems of community life.

\section{On Group Techniques for Attitude Change and Thought Reform}

\section{Misako Nishiyama Kobe College}

Many group techniques are used in attitude change, conversion, and thought reform. In attitude change, group discussion, organizational change, sensibility training group, role playing, psychodrama, sociodrama, and group psychotherapy used. As for conversion, we will take up as example the case of Sokagakkai, a sect of Buddism in Japan. The ardent believers combine in small groups on the first front line in the conversing campaign of the religious organization. In thought reform or "Culture Revolution" of the Red China, various forms of group techniques are found: such as learning movement, thought reform, rectification movement, etc.

We can point out that these methods have affinities and differentials with each other.

As for affinities on each side, small group method is used to bring up an attitude and behavior change. The mechanism of attitude change in group, which works on these fields, tends to enlarge ego-involvement of group members. Consequently, group members become to comformity to the norm of the membership group, or the change of the norm of membership group accompany with the attitude and behavior change of group members.

As for differentials, we will try to compare between the group techniques of the behavior sciences and those used in the Red China. The differentials may be summarised as follows: 


\section{A Critique of the Study Made about}

\section{Community Power Structure}

- Its problems, methods and views in the United States -

\section{Sumiko Yoshihashı \\ University of Tokyo}

Since Floyd Hunter undertook the research about community power structure in 1953, many sociologists and political scientists have renewed their interests on community study. A great number of empirical studies about community power structure (CPS) have been cumurated since then. Behind this rapid increase of CPS study since 1953, I find the great change made in community life and the policy-oriented response of social scientists toward the changing community and its policy made by local government.

1) Some problems of CPS.

Dealing with the problem of CPS, CPS students focused their view on community, especially political community. Their main interests was how to develop more effective research techniques to analyse the political community and political behaviour of local elites. The most important problem for them was to rebuild democracy in community with their policy-oriented ideology of community and technological theory of CPS.

2) Some approaches to CPS.

Three dominant approaches to CPS can be distinguised; reputational, decisional and organizational ones. The first two approaches and the CPS models which they presented about the political community and political behaviour of local elites were often discussed in the dispute about CPS between "elitists" and "pluralists". The fourth approach was presented in 1960' supported by the strong demand of " policy science" research in community study. It was experimental approach. Those approaches to CPS are characterized with much empiricism and subjective idealism.

3) Some views on CPS

All the views of CPS students except C.W. Mills didn't see the structural relationships between local and national society. They could not admit the decline of democracy. In addition, all the views of CPS students are characterized with elitism. They omitted the mass or ordinary citizens of 